\title{
Um Estudo Analítico da Sonata para flauta (1941) de Cláudio Santoro
}

\author{
Analytical Study of Cláudio Santoro's \\ "Sonata for flute" (1941)
}

\author{
Alessandro Santoro \\ Escola de Música do Estado de São Paulo (EMESP Tom Jobim) \\ santoro.alessandro@gmail.com
}

Resumo: Este estudo aborda a Sonata para flauta e piano (1941) escrita por Cláudio Santoro durante os primeiros anos da Segunda Guerra Mundial, como membro atuante do Grupo Música Viva. Esta Sonata representa um marco histórico da música brasileira pois se trata de uma das primeiras obras de envergadura no repertório camerístico a empregar com plena consistência os princípios da técnica dodecafônica que apenas começava a ser difundida no Brasil. A peça estava extraviada e descreve-se as circunstâncias de sua recuperação. Demonstra-se a ligação da obra com o repertório que Santoro executava, tanto quanto à escolha do gênero, quanto à concepção da forma e influências estilísticas. Diversos aspectos da técnica dodecafônica empregada são analisados, relacionando os parâmetros estudados com a construção formal da peça para demonstrar o domínio do compositor da linguagem atonal desde suas primeiras obras no estilo.

Palavras-chave: Cláudio Santoro; técnica dodecafônica; sonata para flauta; música brasileira do século vinte.

Abstract: This study deals with the Sonata for flute and piano (1941) written by Cláudio Santoro during the initial years of the Second World War, being an active member of the "Música Viva" group. This Sonata represents a historical landmark for the Brazilian music inasmuch it is one of the first large works of the chamber repertoire that employs with full consistency the principles of the twelve-tone technique that had only begun to be taught in Brazil. The piece had been lost and the circumstances of its recovery are described. The study also demonstrates the connection of this piece with the repertoire that Santoro used to perform, both in respect to the choice of genre, as to the conception of form and stylistic influences. Many aspects of the twelve-tone technique employed are analyzed, relating the studied parameters $w$ ith the formal construction of the piece to prove his knowledge of the atonal language since his initial attempts in the style.

Keywords: Cláudio Santoro; twelve-tone technique; sonata for flute; $\mathrm{XX}^{\text {th }}$ Century Brazilian music. 


\section{1 - Contexto Histórico}

"No fundo no fundo eu sou um clássico porque procuro a forma."

Cláudio Santoro

"Les œuvres d'art font les règles, les règles ne font pas les œuvres d'art."

Claude Debussy

Em plena turbulência da Segunda Guerra Mundial, tendo a Alemanha invadido a Rússia há menos de um mês, a manchete do jornal "Correio da Manhã" do Rio de Janeiro dia de 10 de julho de 1941 anunciava: "Forças Navais dos Estados Unidos receberam ordem para manter livres as rotas marítimas através do Atlântico". Neste mesmo dia Santoro, aos 21 anos, concluía sua Sonata para flauta e piano dedicada a Hans Joachim Koellreutter.

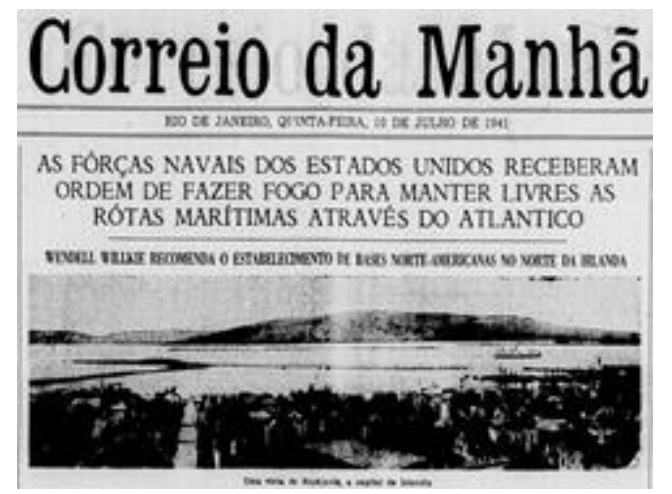

Figura 1: Manchete do principal jornal carioca em 10/07/1941

Havia se passado apenas um ano desde a criação da Sonatapara violino solo, publicada posteriormente, obra que o próprio compositor considerava como o início de sua escrita na linguagem dodecafônica.

Para uma melhor compreensão do contexto em que a Sonata para flauta foi escrita e o que influenciou Santoro nas escolhas de sua construção, forma e estilo, dividiremos o estudo das atividades de Claudo Santoro em três partes, evidenciando o relacionamento entre elas:

- composição

- integrante do Grupo Música Viva: aulas com Koellreutter ${ }^{1}$, artigos publicados nos Boletins e apresentações

- atuação como violinista

\footnotetext{
${ }^{1}$ Hans-Joachim Koellreutter (1915-2005) foi um compositor, professor, musicólogo e flautista, nascido na Alemanha, que imigrou para o Brasil onde desempenhou papel de fundamental importância para a música brasileira principalmente nas áreas da composição e da pedagogia.
} 


\subsection{Composição}

Santoro já tinha escrito algumas obras atonais quando conheceu Koellreutter e lhe mostrou a sua Sinfonia No.1 para duas orquestras de cordas, obra que utilizava princípios do serialismo. Não por acaso, aquela Sinfonia foi escrita no mesmo mês da Sonata para Violino Solo, obra que marca a mudança de caminhos trilhados na composição por Santoro neste período.

Na entrevista à Folha de São Pauloº ${ }^{2}$ Koellreuter respondendo à pergunta de como ele tinha introduzido o dodecafonismo e o serialismo no Brasil, ele explica que

... em 40, quando eu ensinava composição a Cláudio Santoro, ele fazia a "Sinfonia para duas orquestras de cordas", com trechos que já traziam essas técnicas em embrião. Ele me perguntou o que era dodecafonia. Eu não o forcei a fazer. Eu dava aulas de acordo com minha orientação estética. Ele estudou em conservatório e ouviu falar disso, mas não foi informado. No fundo ele me obrigou, com as perguntas que me fez, a estudar mais a coisa. E escrevi Invenção, o primeiro trio rigorosamente dodecafônico. Mas quem me levou a fazer isso a sério foi o Santoro.

Em entrevista a Raul do Valle, Santoro também fala a respeito desta época:

Comecei a compor música no Brasil em 39/40, música atonal e depois em 1940, fazendo música com serialismo, dodecafonismo, com uma certa serialização à minha maneira, porque não havia nada codificado sobre isso, não existia teoria nem nada. Foi muito posteriormente que surgiu o primeirolivro de contraponto dodecafônico. Quer dizer, nessa época, quando apareceu esse livro no Brasil, eu já tinha seis anos de música escrita, dodecafônica, serial³.

Na época da Sonata para flauta, Santoro já tinha desenvolvido um uso particular nesta nova técnica. Mas o importante é o que movia Santoro a escrever de forma atonal. Em suas memórias Santoro descreve este processo que o levou a escrever em uma linguagem tão contemporânea para o Brasil daquela época:

Foi muito difícil para mim, no início, compor. Eu não tinha piano e tinha que transcrever aquilo que estava na minha cabeça, mas confesso que era muito difícil. Confesso que era muito difícil porque era muito nebuloso, o que eu ouvia interiormente eu não conseguia ter a técnica para poder transcrever no papel aquilo que eu imaginava em música. É muito interessante isso porque depois que ouvi pela primeira vez algumas coisas eletrônicas ou feitas através de processos

\footnotetext{
2 Entrevista de 7 de novembro de 1999 à Folha de São Paulo - “A revolução de Koellreutter Lições de vanguarda

${ }^{3}$ Santoro apud Souza 2003, p.79 relata entrevista concedida por Cláudio Santoro ao compositor Raul do Valle, em Heidelberg, Alemanha, em 1976.
} 
eletroacústicos - era isso que eu ouvia, era isto que eu queria fazer naquela época, e que eu não pude fazer, porque não tinha os meios de como fazer, porque só podia ser dois meios: ou através de uma improvisação orquestral, que eu não tinha os meios portanto de grafar e depois ter os meios de gravar, ou então ter esses aparelhos que nessa época, por volta de 1937/38/39 não se pensava nesse assunto ou, se se pensava no Brasil, o Rádio estava nascendo, quando muito a gente queria fazer alguma coisa que usasse processos eletroacústicos. Tanto assim que depois a técnica dodecafônica foi um meio que eu encontrei para que eu pudesse transcrever um pouco mais aquilo que eu sentia. Fui naturalmente entrando num certo "rigorismo", vamos dizer assim, musical - fui me adaptando à técnica para expressar o meu pensamento, tanto que, eu nunca usei a técnica dodecafônica, era uma técnica minha mesmo - não havia nada no início quando comecei a escrever com os 12 sons - antes dos 12 sons eu procurava fazer algumas coisas atonais, que não tinham relações tonais, eu sempre criava a temática ou o complexo temático, harmonia, tema, ou tema e harmonia, e daí eu tir ava a série, muitas vezes ela era completa e muitas vezes eu tinha que completá-la com mais duas ou três notas ou duas notas ou uma nota que faltava para completar a série. Aí eu então compunha sempre de maneira muito livre, nunca de uma maneira assim ultra rigorosa. Criei a minha maneira de fazer, de usar o dodecafonismo, porque até então não havia nada preestabelecido para, vamos dizer, organizar esta nova técnica. O livro do Krenek ${ }^{4}$ só apareceu no Brasil lá pelos anos 46, na verdade eu tinha uns sete anos de compor música dodecafônica... ${ }^{5}$

\subsubsection{Obras de Cláudio Santoro escritas entre 1940 a 42}

A lista de obras escritas por Santoro entre 1940 e 1942 (Tabela 1), evidencia sua produção e o desenvolvimento adquirido nesta técnica de composição.

\begin{tabular}{|c|c|}
\hline Data & Obra \\
\hline \multicolumn{2}{|l|}{1940} \\
\hline $12 / 1939$ a $04 / 1940$ & Sonata $\mathrm{n}^{\mathrm{o}} 1$ para violino e piano \\
\hline $30 / 05 / 1940$ & Trio para clarineta, oboé e fagote \\
\hline $09 / 1940$ & Sinfonia $\mathrm{n}^{\mathrm{o}} 1$ para 2 orquestras de cordas \\
\hline $09-1940$ & Sonata para violino solo \\
\hline \multicolumn{2}{|l|}{1941} \\
\hline sem data & Divertimento para 7 instrumentos \\
\hline sem data & Sinfonia de Câmara \\
\hline $1941(?)$ & Quarteto de cordas $\mathrm{n}^{\mathrm{o}} 1$ \\
\hline $03 / 06 / 1941$ & Sonata $\mathrm{n}^{\mathrm{0}} 2$ para violino e piano \\
\hline $10 / 07 / 1941$ & Sonata para flauta e piano \\
\hline \multicolumn{2}{|l|}{1942} \\
\hline sem data & Adágio para cordas \\
\hline sem data & Três Peças para clarineta \\
\hline
\end{tabular}

4 Ernst Krenek (1900-90) - Studies in Counterpoint based on the Twelve-Tone Technique (1940)

5 Santoro: “Contando minha vida" (1986). 


\begin{tabular}{|c|c|}
\hline sem data & Pequena Toccata para piano \\
\hline sem data & Quinteto de Sopro \\
\hline sem data & Três pequenos divertimentos para orquestra de câmara \\
\hline $21 / 01 / 1942$ & Trio para violino, viola e violoncelo \\
\hline $24 / 01 / 1942$ & Invenção a duas vozes para piano \\
\hline $29 / 01 / 1942$ & Sonata 1942 para piano \\
\hline $05 / 03 / 1942$ & 4 Epigramas para flauta solo \\
\hline $04 / 09 / 1942$ & Sonatina a três para flauta, viola e violoncelo \\
\hline
\end{tabular}

Tabela 1: Relação das obras de Cláudio Santoro escritas entre 1940 a 42

\subsection{Música Viva}

As atividades de Santoro como compositor tinham ligação direta com a sua relação com Koellreutter e os caminhos estéticos tomados pelo Grupo Música Viva. Segundo Kater, o Música Viva foi um movimento musical concebido em 1938 sob o tríplice enfoque: Educação, Criação e Divulgação.

Kater resume de forma precisa a enorme importância deste movimento cultural criado por Koellreutter:

A dinâmica que impôs no meio musical gerou um forte e raro movimento em nossa cultura. Produziu polêmica e forçou a tomada de posição de praticamente todos os músicos e artistas de seu momento. Mas de fato o que de melhor provocou foi a reflexão sobre o papel da música na sociedade, sua função junto ao seu próprio tempo; a inquietação diante da criação contemporânea, do homem novo de cada dia e da responsabilidade do artista diante das problemáticas fundamentais de sua época. O movimento Música Viva está na base de algumas das mais significativas realizações musicais do país e criou a expressão-estandarte Ideias são mais fortes do que preconceitos. Com tudo isto introduziu o que consideramos hoje a "Segunda Fase da Modernidade Musical Brasileira" (Kater 2001, p. 23).

Sempre preocupado com a função da música na sociedade, Santoro participava intensamente de todas as atividades do grupo, assim como publicava artigos no Boletim Musica Viva, onde discutia seus posicionamentos estéticos. Os artigos que publicou no Boletim foram os seguintes:

SANTORO, Cláudio. Março de 1941. Considerações em torno da música brasileira contemporânea (I). Música Viva, Rio de Janeiro, $\mathrm{n}^{\circ}$ 9, ano I, p. 03.

SANTORO, Claudio. Abril/maio de 1941. Considerações em torno da música contemporânea nacional. Música Viva, Rio de Janeiro, $\mathrm{n}^{\circ} 10$, ano I. 
A preocupação com a questão estética, que sempre acompanhou Santoro em toda sua vida, é compartilhada claramente no manifesto publicado alguns anos depois por integrantes do Música Viva, demonstrando o espírito livre e avantgard do grupo.

\section{Manifesto: 1 de maio de 1944}

O grupo Música Viva surge como uma porta que se abre à produção musical contemporânea, participando ativamente da evolução do espírito.

A obra musical, como a mais elevada organização do pensamento e sentimentos humanos, como a mais grandiosa encarnação da vida, está em primeiro plano no trabalho artístico do Grupo Música Viva.

Música Viva, divulgando, por meio de concertos, irradiações, conferências e edições a criação musical hodierna de todas as tendências, em especial do continente americano, pretende mostrar que em nossa época também existe música como expressão do tempo, de um novo estado de inteligência.

A revolução espiritual, que o mundo atualmente atravessa, não deixará de influenciar a produção contemporânea. Essa transformação radical que se faz notar também nos meios sonoros, é a causa da incompreensão momentânea frente à música nova.

Idéias, porém, são mais fortes do que preconceitos! Assim o Grupo Música Viva lutará pelas idéias de um mundo novo, crendo na força criadora do espírito humano e na arte do futuro.

Aldo Parisot, Cláudio Santoro, Guerra Peixe, Egydio de Castro e Silva, João Breitinger, Mirella Vita, Oriano de Almeida, H. J. Koellreutter

Os compositores do grupo não somente compunham, mas os seus próprios integrantes executavam e estreavam as obras em concertos e programas de rádios, desde os anos 1940.

Enquanto Kater relata que a primeira audição do Música Viva foi em 11 de junho 1939, Santoro descreve o tipo de música que ele estava acostumado de ouvir no Brasil daquela época:

A única coisa que a gente ouvia ainda era o Ravel, Debussy, Roussel - que os regentes vinham e regiam - o Prokofiev mesmo também, que nós chegamos a tocar na OSB, mas isto muito posteriormente quando eu já estava compondo bastante música dodecafônica. Depois desse período, eu com as minhas ideias filosóficas, partidárias, achando que devia contribuir com a minha arte para o meu povo - o que acho até hoje - eu achava que o que eu estava fazendo estava muito distante - uma ideia minha - não sei se hoje foi bom ou ruim - mas o fato é que algumas dessas obras do meu primeiro período dos anos 40, têm muitas coisas que até hoje são tocadas - e elas ficaram - porque eu acho que, principalmente, eu nunca perdi o senso humanista da minha obra e também o senso formal' (Santoro 1986).

\footnotetext{
${ }^{6}$ Santoro, contando minha vida, 1986
} 
Os jornais da época que apoiavam o Música Viva atestam a frequência das atividades do grupo, seja em publicação de artigos, composições ou concertos, desde $1940^{7}$.

A respeito da sua relação com Koellreutter, Santoro relatou:

Estudei com Koellreutter mais técnica, estudei contraponto muitas discussões estéticas. Trabalhei diariamente com ele contraponto durante um ano e pouco, toda parte da polifonia eu fiz com ele, muito seriamente, intensivamente, diariamente. Sob o ponto de vista da técnica da composição, aprendi muitas coisas com ele. A técnica que ele usava era a de Hindemith, mas ele também estava começando a pesquisar sobre serialismo. Ele trouxe as ideias do Schoenberg e só me ensinou como se faz uma série e mais nada e daí em diante eu que trabalhei à minha maneira ${ }^{8}$ (Santoro 1986).

\subsection{Atividades como violinista}

Santoro participava ativamente da vida artística da capital, como músico da Rádio, em conjuntos de câmara, na Orquestra Sinfônica Brasileira ou como solista apresentando obras de própria autoria.

Com a necessidade de se sustentar, Santoro participava como violinista também de diferentes atividades musicais que a cidade oferecia:

No princípio foi meio duro, lógico, porque tinha pouco trabalho, depois arranjei um lugar na Rádio Tupi, para tocar violino numa orques trinha que se chamava Orquestra de Salãona época, mas a gente tocava o material da orquestrinha - que era uma flauta, um violino (eu), um violoncelo (creio), às vezes tinha uma clarineta e piano - e a gente tinha que tocar tudo, aquelas aberturas, aqueles potpourris, onde a gente tocava todas as deixas - entrava um trompete, eu tocava um trompete - tocava-se tudo! Foi uma escola ótima porque a gente aprendia a ler música de uma maneira incrível ${ }^{9}$ (Santoro 1986).

Acreditamos ser possível estabelecer uma conexão entre as atividades de Santoro como violinista, sua relação com o seu professor Koellreutter, o conjunto no qual se apresentavam, o repertório que executavam e a influência destes elementos na concepção da Sonatapara flauta.O prelúdio desta conexão é descrito em um relato do próprio compositor:

A minha professora de Harmonia, que era compositora também - mostrei outros trabalhos para ela e ela ficou muito entusiasmada e o próprio Guerra ${ }^{10}$ também

\footnotetext{
${ }^{7}$ Nos anexos, selecionamos exemplos desses artigos de jornais da época.

8 Santoro apud Oliveira, 2005, p.66: Depoimento concedido a Sérgio Nepomuceno. Rio de Janeiro, 22 dez. 1986.

9 Santoro, contando minha vida, 1986.

${ }^{10}$ Edgard Guerra - professor de violino do Conservatório de Música do Rio de Janeiro.
} 
me disse: "Ah, faz uma peça para violino solo" e fiz uma peça para violino solo - ele era compositor também e ele me entusiasmou. Eu fui me entusiasmando assim, até que eu fazia (tocava) sonatas com uma pianista, Ballarin ${ }^{11}$, filha de italianos - e um dia li uma peça minha para violino e piano - nem me lembro o que foi, uma tentativa dessas de composição - e ela disse: “Ah, sabe, tem uma pessoa aí, com quem estou estudando cravo, que é o Koellreutter, que vem da Alemanha, está aqui refugiado" - isso eram os anos 39, e já havia guerra - "e vou te apresentar para ele" - e me apresentou. Eu mostrei alguns trabalhos que já tinha feito, tinha feito uma tentativa de uma sonata para violino e piano e uma outra tentativa de um quarteto - e ele não acreditou que eu nunca tivesse ouvido nem Schoenberg, nem Hindemith, nem coisa nenhuma e fazia coisas assim, atonais - ficou muito admirado e disse que me ensinava, me ensinava imediatamente. Então comecei a trabalhar com ele, principalmente contraponto, e discussão estética, problemas estéticos na música contemporânea e tudo m ais o que era para nós contemporâneo na época, a única coisa que a gente ouvia mais, era que havia alguns discos que vinham dos Estados Unidos, etc. Fizemos muita amizade, não só foi uma relação de professor para aluno, mas também uma relação de amizade profunda que nós tínhamos na época - o Koellreuter lutava muito, não era brincadeira. Logo em seguida, um ano depois, a Orquestra Sinfônica Brasileira foi fundada e ele também veio para tocar flauta - e eu tocava na Orquestra também. Nesse ínterim ele foi embora para São Paulo - acho que o Brasil entrou na guerra em 42 se não me engano, e ele já estava em São Paulo quer dizer que trabalhei com ele um ano e meio mais ou menos. Depois eu ainda mandava alguns trabalhos lá para São Paulo e ele mandava sugestões e as correções, e as sugestões dele, o que ele achava e as críticas dos trabalhos ${ }^{12}$ (Santoro 1986).

O conjunto formado por Santoro, Koellreutter e Ballarin (violino, flauta e cravo) apresentava-se frequentemente em concertos e na Rádio com obras barrocas, como pode ser comprovado pelos inúmeros artigos publicados no jornal Correio da Manhã do Rio de Janeiro. Apresentações do conjunto registradas pelo Correio da Manhã (coluna Correio Musical) aparecem nos jornais de 30-08-1940; 06-06-1941; 05-10-1941; 23-10-1941; 28-02-1942 ${ }^{13}$.

Kater descreve que na época em que a Sonata para flauta foi escrita, Santoro deixou de ser aluno para virar colega de Koellreutter no Música Viva no fim de 1941, fato que coincide com a mudança de Koellreutter para São Paulo, relatada em jornal na época ${ }^{14}$.

O contato e a troca de ideias entre estas duas personalidades continuaram intensamente. Um dos frutos desta relação seria a própria Sonata para flauta que foi escrita, dedicada e estreada por Koellreutter.

\footnotetext{
${ }^{11}$ Gabriella Ballarin - pianista.

12 Santoro, contando minha vida, 1986

${ }^{13}$ Relacionamos apenas alguns registros dentro do período em que a Sonata para flauta foi escrita. Ver anexos.

14 Ver anexos.
} 
Posteriormente Santoro ainda dedicou a Koellreutter os 4 Epigramas para flauta solo, de março de 1942. Em alguns dos manuscritos desta obra, é evidente a troca de ideias entre os dois compositores.

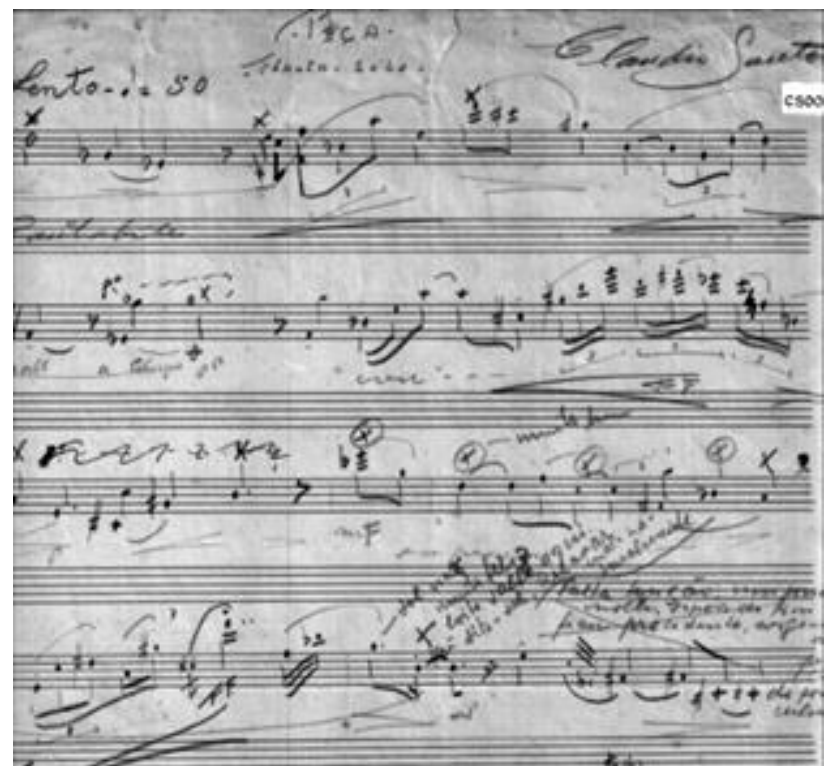

Figura 2: Excerto de um dos 4 Epigramas para flauta de Cláudio Santoro, com sugestões manuscritas de Koellreutter

Assim, apesar da discrepância entre a data de estreia que consta no catálogo e aquela publicada no jornal, é natural que tenha sido o próprio Koellreutter que estreasse a Sonata para flauta, como atesta o jornal (Figura 3). Vale destacar que nesse artigo, escrito pela compositora Dinorah de Carvalho ${ }^{15}$ no jornal "A Manhã" do Rio de Janeiro de 3 de outubro de 1942, fica evidente a escolha da linguagem da Sonata para flauta para combinar com o contexto específico das outras obras programadas para este concerto ${ }^{16}$.

\footnotetext{
${ }^{15}$ Dinorah de Carvalho - (1905-1980), pianista e compositora

16 Transcrevemos a seguir as partes do artigo mais significativas para nossos propósitos: "Com obras de J. S. Bach, G. Fr. Haendel, Claudio Santoro, J. Pachelbel e G. Ph. Teleman, a “Sociedade Bach" ofereceu mais uma interessante audição aos seus sócios... Na última parte, ouvimos em primeira audição, a Sonata para piano e flauta, de autoria do jovem compositor brsileiro (sic), Cláudio Santoro. Essa Sonata é atonal enão tem influências folclóricas. Trata-se de um compositor bastante original, talvez o único entre nós que escreve no sistema "Schoenberg" em doze tons. A execução do flautista Koellreuter, foi notável, com a técnica perfeita e clareza de sonoridade.
} 


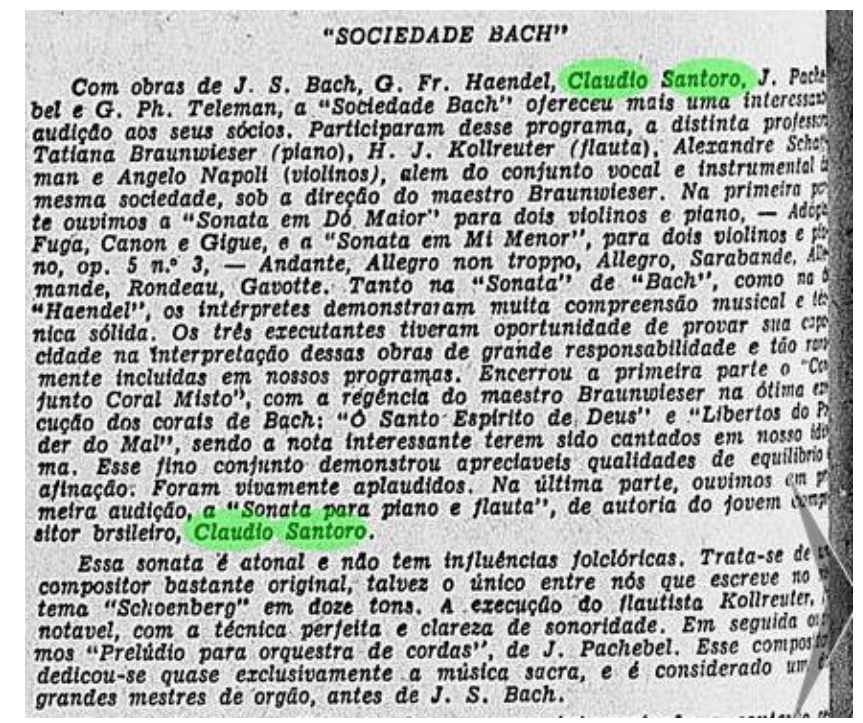

Figura 3: Artigo de Dinorah de Carvalho no jornal “A Manhã” Rio de Janeiro 3/10/1942

Santoro tinha uma forma bastante individual de escrever nesta técnica. Testemunha isto um relato de suas memórias em que ele descreve as impressões de Eleazar de Carvalho ${ }^{17}$ sobre suas obras dodecafônicas.

Assim a minha primeira Sonata para violino solo, as Três peças para clarinete, os Quatro Epigramas para flauta solo, essas peças assim, a Sonatina para oboé e piano, que foram escritas todas numa técnica dodecafônica muito especial, muito minha e que o Eleazar de Carvalho quando executou 22 anos depois a minha Música Concertante para Piano e Orquestra 43 (1943-44), ele me escreve no dia seguinte de Bruxelas para a Alemanha - é, eu estava na Alemanha creio, exatamente, eu estava - ele escreve para mim - ou no Brasil - dizendo: "depois da execução da tua obra, e que a Jocy ${ }^{18}$ fez uma análise muito boa e tocamos muito bem, foi muito bem tocado por ela" - e foi mesmo, tenho a gravação - "eu pergunto a você:" - ai ele escreve um dos temas dessas quatro miniaturas para piano e orquestra "você, quando escreveu isso, já conhecia a obra do Schönberg?" - e eu não conhecia - disse: "se você não conhecia ou tinha alguma iniciativa pelo Koellreutter, entende assim: “Mon cher, vous êtes un génie!” - ah, não acredito tanto, não chega a tanto ${ }^{19}$ (Santoro 1986).

\section{2 - Gênese e Recuperação da Sonata para flauta}

No catálogo de Santoro consta a existência de uma Sonata para flautae piano (catálogo 3.22), em 3 movimentos:

\footnotetext{
17 Eleazar de Carvalho(1912-1996) - eminente regente orquestral e compositor.

18 Jocy de Oliveira (1936) - compositora e pianista que estreou várias obras de Santoro.

19 Santoro, contando minha vida, 1986
}

\section{MUSICA THEORICA}

Revista da Associação Brasileira de Teoria e Análise Musical Journal of the Brazilian Society for Music Theory and Analysis @ TeMA 2017 - ISSN 2525-5541 
1- Lento, Allegretto, Lento

2- Andante

3- Allegretto quasi presto

A obra foi estreada por H. J. Koellreutter e Tatiana Braunwieser em São Paulo, no dia 24 de setembro de $1942^{20}$.

Em 1986 Santoro relata:

Das sonatas para violino, a Sonata para violino solo se mantém, embora tenha sido praticamente a minha primeira obra, e a Sonata no 3, que considero também uma boa sonata - e está saindo uma gravação com o Polyzoides ${ }^{21}$. E a Sonata no 5 - a quarta é muito tocada, mas é uma Sonata que eu fiz pensando mais para jovens, e que é de mediana dificuldade. A Sonata para flauta ficou perdida. A Sonatina para oboé eu gosto muito, a Gisèle 22 também gosta muito, muito curta, mas foi da minha época dodecafônica - foi uma das primeiras obras que impressionou os críticos no Rio de Janeiro, como o Eurico Nogueira França ${ }^{23}$ que escreveu aliás muito bem sobreela, e sobrea primeira Sonata para violino solo também. Os Duos que fiz recentemente para trompa, fagote e piano, o Quinteto de Sopro que é uma obra de 1942 - uma obra muito da juventude - mas o Quarteto de Sopros é um quarteto que me representa. A Fantasia para violino e orquestra, que instrumentei mais recentemente, faz uns 3 anos, era um concerto para violino, era o primeiro movimento no meu 2o Concerto para Violino que não consegui terminar, tanto que o segundo movimento, Andante, eu tirei e transformei numa Fantasia para violino e orquestra - foi tocada muito bem pela Fukuda ${ }^{24}$, em um concerto de obras que eu regi, há 3 anos atrás no Rio de Janeiro, assim como o Concerto Grosso para quarteto de cordas e orquestra. Essas são possivelmente, mais ou menos, as obras que considero que podem talvez ficar ${ }^{25}$ (Santoro 1986).

Devemos esclarecer como a Sonata para flauta, considerada desaparecida pelo próprio Santoro, foi recuperada e recentemente editada. Como ela constava do acervo do compositor, havia muita procura por parte de pesquisadores, acadêmicos e músicos, seja para pesquisa, execução e/ou gravação, etc.

Acadêmicos que publicam trabalhos sobre Santoro habitualmente enviam cópias de seus trabalhos para o acervo de Santoro em Brasília. Foi lá que me familiarizei com o trabalho de Ayres Potthoff ${ }^{26}$, sobre a obra para flauta de Santoro. Nesta época, já responsável pelo acervo, não tinha sido feito ainda um levantamento mais extensivo comparando as obras que se encontravam no

${ }^{20}$ Data que consta do catálogo, porém considerada duvidosa, porque difere da data de estreia da publicação no jornal.

${ }^{21}$ Christos Polyzoides - violinista grego.

22 Gisèle Santoro (1937) - segunda esposa de Claudio Santoro.

${ }^{23}$ Eurico Nazaré Nogueira França (1913-1992) - crítico e musicólogo; redator e crítico de música dos jornais Correio da Manhã e Última Hora e da revista Manchete.

${ }^{24}$ Elisa Fukuda - violinista.

${ }^{25}$ Santoro, contando minha vida, 1986.

${ }^{26}$ Potthoff, Ayres Estema. 1997. A música de câmara com flauta, composta por Cláudio Santoro entre 1940 e 1946 uma abordagem fenomenológica. 125p. Dissertação de Mestrado. UFRJ.

\section{MUSICA THEORICA}


acervo com aquilo que constava no último catálogo das obras concluído por Jeanette Herzog Alimonda $^{27}$ após o falecimento de Santoro em 1989 e que posteriormente transformou-se na base para o catálogo que está online desde 1999. Este levantamento foi realizado por mim em 2007, quando constatei a falta de inúmeras obras no acervo. A maioria destas obras desaparecidas eram obras de câmara, confirmando a suspeita que Santoro, em uma época sem as facilidades de se produzir cópias, muitas vezes dedicava e presenteava o original das obras aos músicos que as executavam ou estreavam, entregando o seu único manuscrito e ficando sem nenhum exemplar da obra. Não foi diferente com a Sonata para flauta.

Ao mesmo tempo, cópias da Sonata para flauta circulavam e mantinham o interesse sobre a obra, para ser executada, estudada e analisada academicamente.

Depois de receber inúmeros pedidos referentes à Sonata, em 2010 entrei em contato com Ayres Potthoff que prontamente me enviou a cópia da Sonata que tinha. A surpresa foi que esta cópia não era da mão de Santoro, mas havia sido realizada pelo compositor e flautista austríaco-argentino Esteban Eitler ${ }^{28}$.

A partir do esclarecimento de Potthoff que o original da cópia de Eitler se encontrava na Escola de Música de Piracicaba, obtive também um outro exemplar desta mesma versão.

As cópias estavam bastante apagadas, criando-se a necessidade de recuperar e finalmente editar esta obra que preenche uma lacuna importante na produção de Santoro daquele período, ainda mais por ser sua única Sonata para flauta e piano.

Utilizando diversos critérios de interpretação da escrita típica de Santoro, observadas em outros manuscritos de obras desta época, é possível observar que Eitler aparentemente tomou muito cuidado em respeitar as idiossincrasias da escrita do compositor. Estas características podem ser observadas através do uso ou da falta de diversos elementos, citando apenas alguns:

- ausência de pausas complementares nas partes

- parte da flauta igual ao da grade (sugere um cuidado em manter a escrita do original)

- traços conectando notas (para Santoro, são indicadores de condução das vozes)

- colchetes na parte do piano (Santoro usa frequentemente para indicar que mão toca certas partes dos acordes no piano)

- forma de agrupamento dos colchetes.

As mudanças que Eitler introduziu no original, aparentemente se limitaram à tradução de alguns termos expressivos da música para o espanhol.

\footnotetext{
27 Jeanette Herzog Alimonda - pianista, cravista e amiga de Claudio Santoro.

28 Esteban Eitler (1913-1960) - flautista, compositor. http://w ww .estebaneitler.com.br/sobre/
} 


\section{3 - Análise Serial (Contagem das Séries) e Influências Estilísticas}

Defendemos neste trabalho que a Sonata para flauta de Santoro dialoga em muitos aspectos com elementos típicos de composições de Sonatas escritas no séc. XVIII, ou seja, acreditamos ser possível identificar uma forte influência da linguagem barroca na Sonata para flauta de Santoro.

Entre os elementos barrocos encontrados na Sonata para flauta listamos:

- Estruturação típica das Trio-Sonatas italianas do séc. XVIII, compostas em três movimentos:

- $1^{\circ}$ movimento: intercala partes lentas e rápidas, como no estilo da Sonata da chiesa

- $2^{\mathrm{o}}$ movimento - Andante em forma de Siciliana

- $3^{\text {o }}$ movimento final - textura polifônica a 3 vozes, em forma de uma bourrée

- Construção melódica e elementos rítmicos típicos do barroco

- Uso da fermata e cadências, generalpause, figuras de suspiro

- Uso do contraponto, polifonia, recursos como augmentationem, inversão e stretto

- Uso, transformação e desenvolvimento de motivos como material temático

- Abruptio, noëma (uníssono), figura corta (onde de três notas rápidas, uma tem o valor das outras duas, como por exemplo no dactilus e no anapesto)

Como se trata de música dodecafônica é pertinente apresentarmos a Matriz (Quadrado Mágico de Babbitt) das séries usadas por Santoro nos diversos movimentos dessa Sonata para flauta:

\begin{tabular}{|c|c|c|c|c|c|c|c|c|c|c|c|c|c|c|}
\hline & I8 & I2 & I0 & I5 & I10 & I4 & & I11 & I3 & I6 & I1 & I7 & I9 & \multirow[b]{2}{*}{ R9 } \\
\hline \multirow[t]{2}{*}{$\mathrm{O} 8$} & lab & ré & dó & fá & sib & $\mathrm{mi}$ & 0 & si & re\# & fa\# & do\# & sol & la & \\
\hline & 0 & 1 & 2 & 3 & 4 & 5 & & 6 & 7 & 8 & 9 & 10 & 11 & \\
\hline 2 & ré & sol\# & fa\# & si & $\mathrm{mi}$ & sib & 1 & fá & la & do & sol & do\# & $\mathrm{mib}$ & R3 \\
\hline 4 & $\mathrm{mi}$ & sib & sol\# & do\# & fa\# & do & 2 & sol & si & ré & la & $\mathrm{mib}$ & fá & 5 \\
\hline 17 & si & fá & $\mathrm{mib}$ & sol\# & do\# & sol & 3 & ré & fa\# & la & $\mathrm{mi}$ & sib & do & 20 \\
\hline 6 & fa\# & do & sib & $\mathrm{mib}$ & sol\# & re & 4 & la & do\# & $\mathrm{mi}$ & si & fá & sol & R7 \\
\hline 5 & fá & si & la & re & sol & do\# & 5 & sol\# & do & $\mathrm{mib}$ & sib & $\mathrm{mi}$ & fa\# & R6 \\
\hline & do & fa\# & $\mathrm{mi}$ & la & ré & sol\# & 6 & $\mathrm{mib}$ & sol & sib & fá & si & do\# & 1 \\
\hline & do\# & sol & fá & sib & $\mathrm{mib}$ & la & 7 & $\mathrm{mi}$ & sol\# & si & fa\# & do & ré & 2 \\
\hline 10 & sib & $\mathrm{mi}$ & ré & sol & do & fa\# & 8 & do\# & fá & sol\# & $\mathrm{mib}$ & la & si & 11 \\
\hline O3 & $\mathrm{mib}$ & la & sol & do & fá & si & 9 & fa\# & sib & do\# & sol\# & ré & $\mathrm{mi}$ & 4 \\
\hline 99 & la & $\mathrm{mib}$ & do\# & fa\# & si & fá & 10 & $\mathrm{do}$ & $\mathrm{mi}$ & sol & ré & sol\# & sib & 210 \\
\hline & sol & do\# & si & $\mathrm{mi}$ & la & $\mathrm{mib}$ & 11 & sib & re & fá & do & fa\# & sol\# & R8 \\
\hline
\end{tabular}

Tabela 2: Matriz das séries dodecafônicas usadas por Santoro na Sona ta para flauta 
Detalhamos a seguir as séries usadas por Santoro nos três movimentos da Sonata para flauta. Todas elas são derivadas da série apresentada no inicia da obra, que está inscrita na matriz como O8.
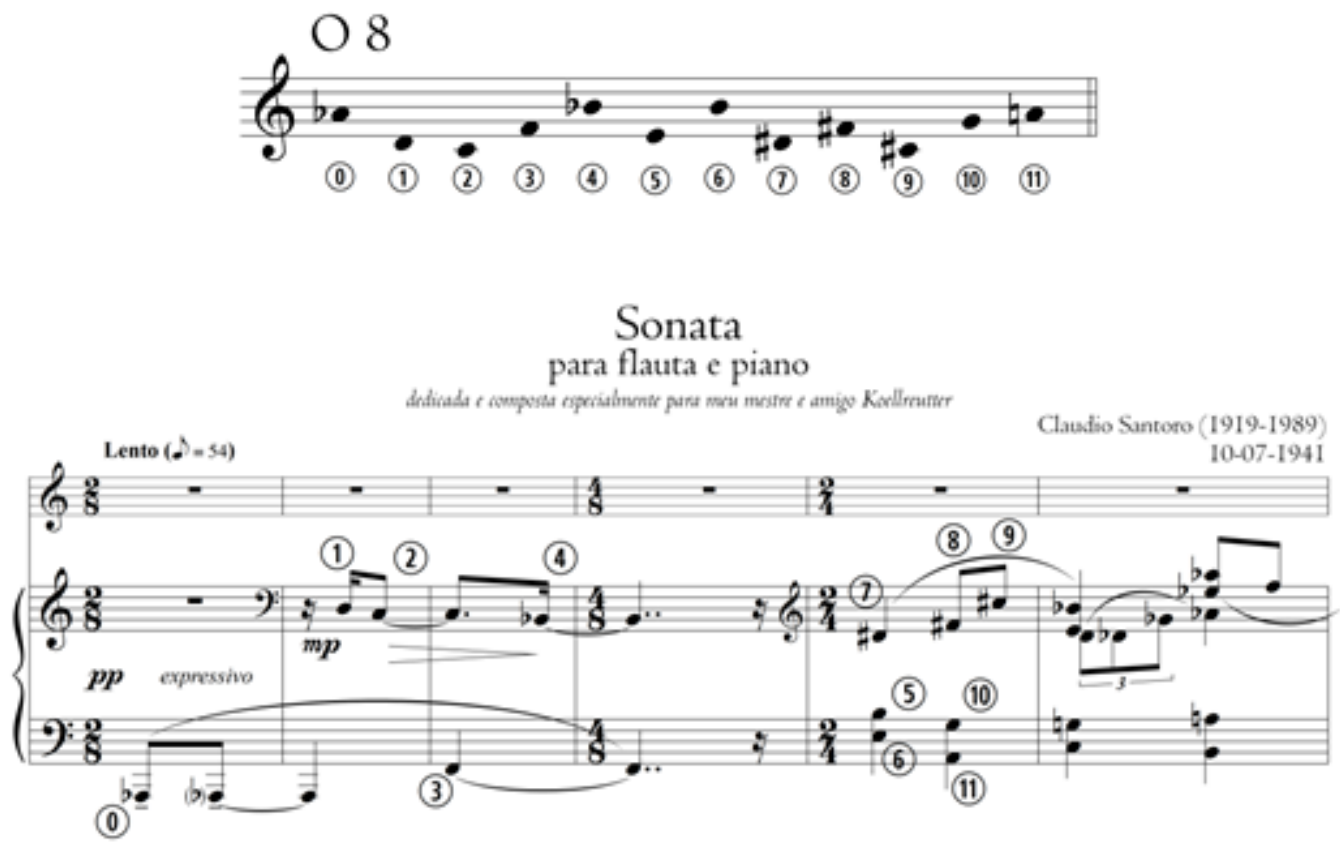

Exemplo 1: Série [O8] e sua aplicação no Primeiro Movimento, 1aㅗ seção, Lento

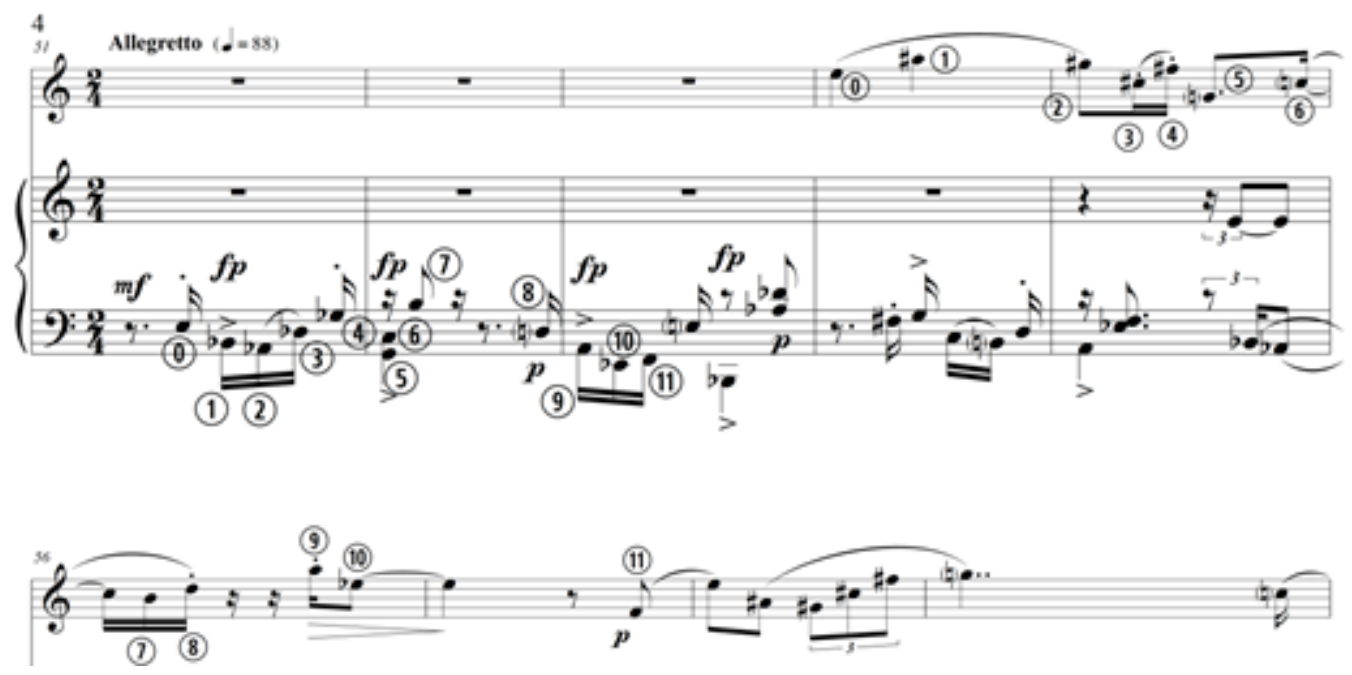

Exemplo 2: Série [O4] e sua aplicação no Primeiro Movimento, 2ª seção, Allegretto 

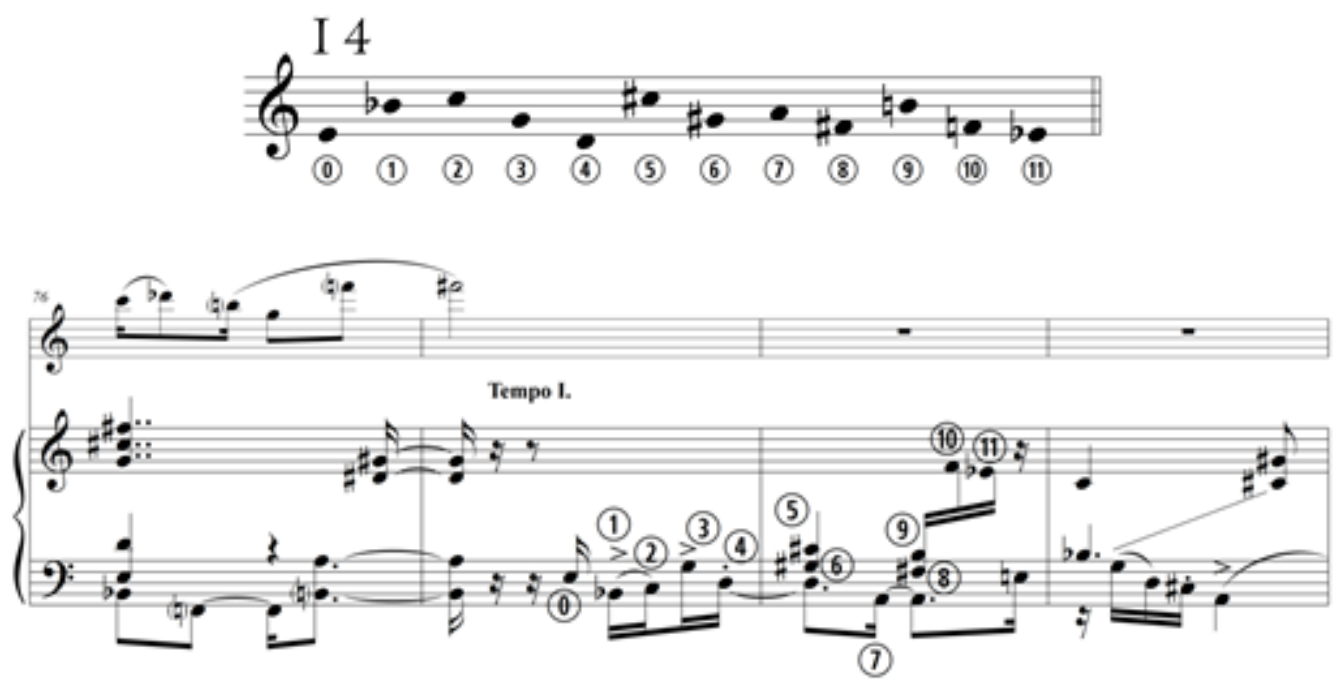

Exemplo 3: Série [I4] e sua aplicação no Primeiro Movimento, 3aㅗ seção, Tempo Primo
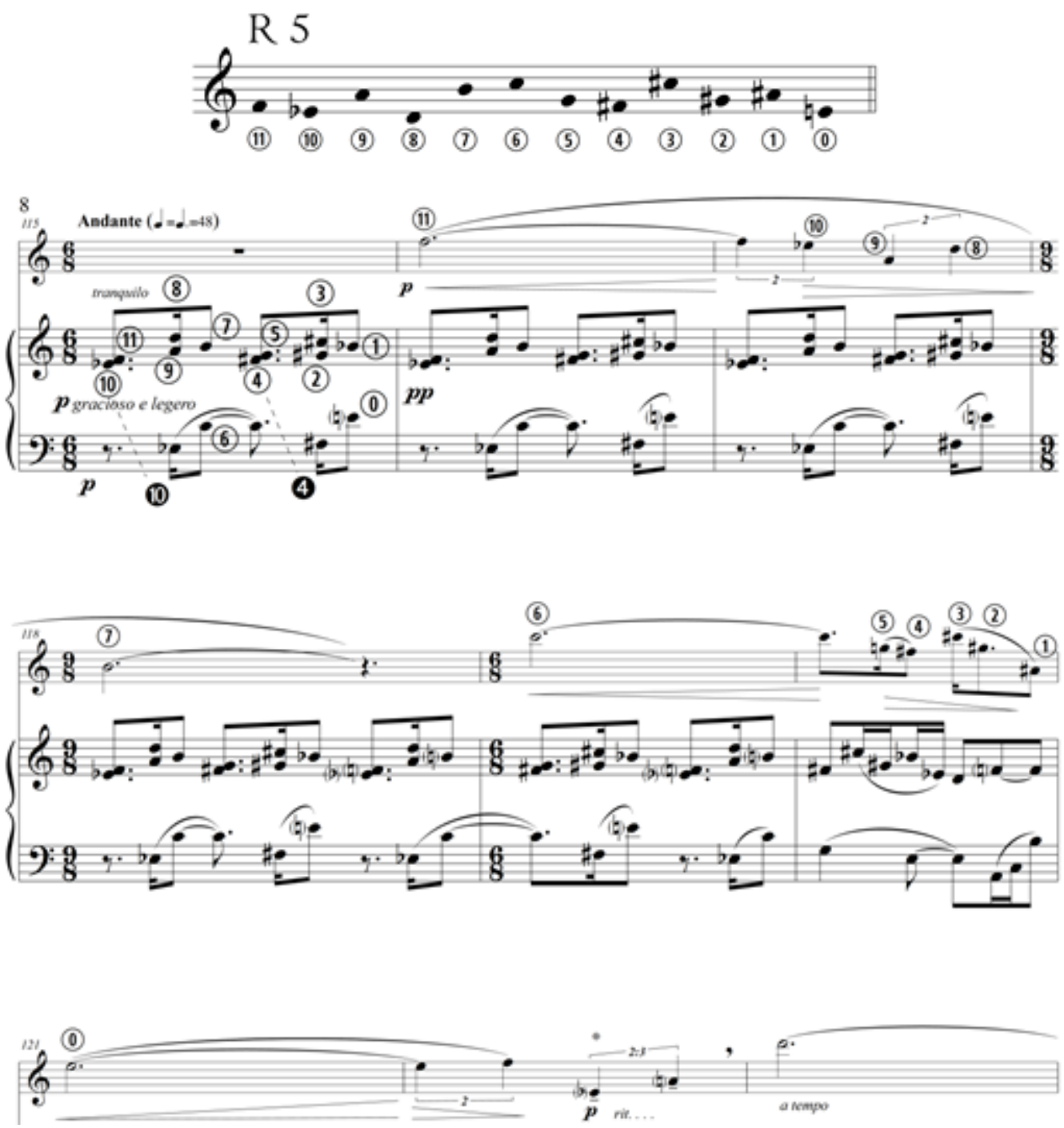

Exemplo 4: Série [R4] e sua aplicação no Segundo Movimento, Tempo I 

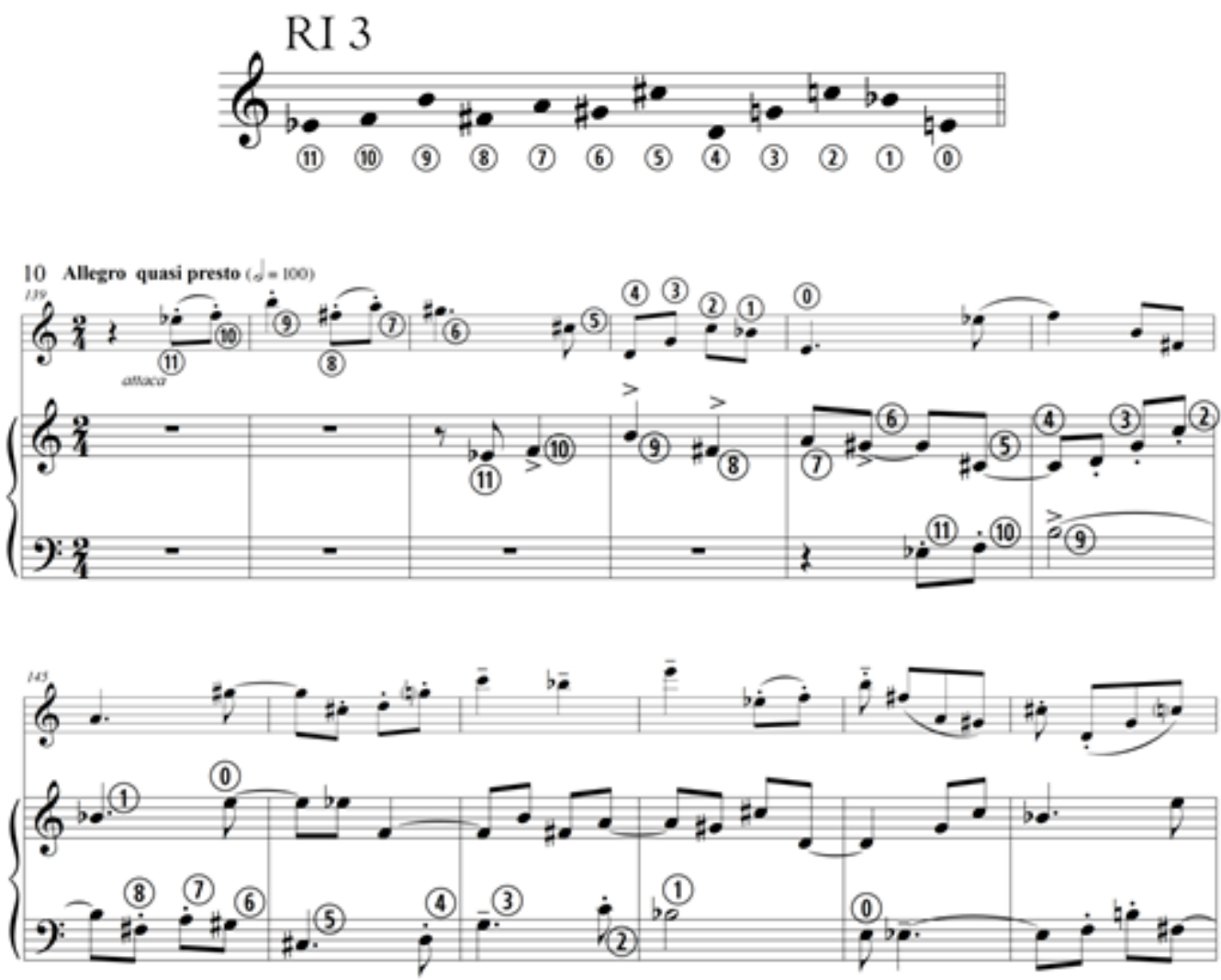

Exemplo 5: Série [RI3] e sua aplicação no Terceiro Movimento, Allegro

\section{4 - Procedimentos Não-Isomórficos de Manipulação das Séries}

Além das operações isomórficas (O-I-R-RI) relacionadas à matriz serial caracterizadas nos Exemplos 1 a 5, reconhecemos diversos outros procedimentos e manipulações da série, muitos convencionais, alguns não-convencionais, utilizados por Santoro na Sonata para flauta, como demonstrado a seguir.

\subsection{Elisão de nota:}

Trata-se de um artifício usual nas obras da Segunda Escola de Viena e que se refere à utilização da nota final de uma série como inicial da seguinte.

\begin{tabular}{|c|c|c|c|c|c|}
\hline mov & compasso & série & nota da série & justificativa & observação \\
\hline $3^{\circ} \mathrm{mov}$ & 153 & RI3 & $11=0$ & série sobe $1 / 2$ tom & RI3 para RI4 no piano \\
\hline $3^{\mathbf{0}} \mathrm{mov}$ & 159 & RI3 & $11=0$ & série sobe $1 / 2$ tom & RI3 para RI4 na flauta \\
\hline $3^{\mathbf{0}} \mathrm{mov}$ & 161 & RI4 & $11=0$ & série sobe $1 / 2$ tom & RI4 para RI5 no piano \\
\hline $3^{\mathbf{0}} \mathrm{mov}$ & 181 & RI4 & $11=0$ & série sobe $1 / 2$ tom & RI4 para RI5 na flauta \\
\hline $3^{\mathbf{0}} \mathrm{mov}$ & 233 & RI3 & $11=0$ & série sobe $1 / 2$ tom & RI3 para RI4 na flauta \\
\hline $3^{\mathbf{0}} \mathrm{mov}$ & 250 & RI5 & $11=0$ & série sobe $1 / 2$ tom & RI5 para RI6 no piano \\
\hline
\end{tabular}

Tabela 3: Elisões da série no $3^{\circ}$ Movimento 
A elisão é utilizada nesta obra como forma de modulação entre uma série e outra. Na maioria dos casos, a série modula subindo de $1 / 2$ tom. Todas as elisões acontecem na parte polifônica do terceiro movimento e com a utilização da série apresentada horizontalmente. O uso desta técnica prova que Santoro já tinha, a esta altura, pleno domínio dos artifícios seriais usados pela escola de Schoenberg.

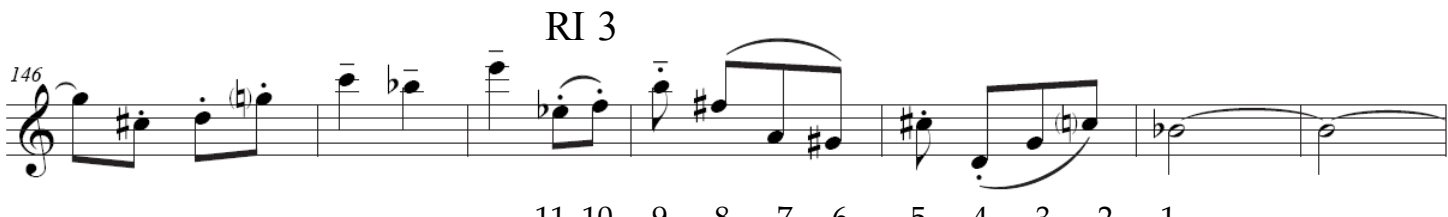

$\begin{array}{lllllllllll}11 & 10 & 9 & 8 & 7 & 6 & 5 & 4 & 3 & 2 & 1\end{array}$

RI 4

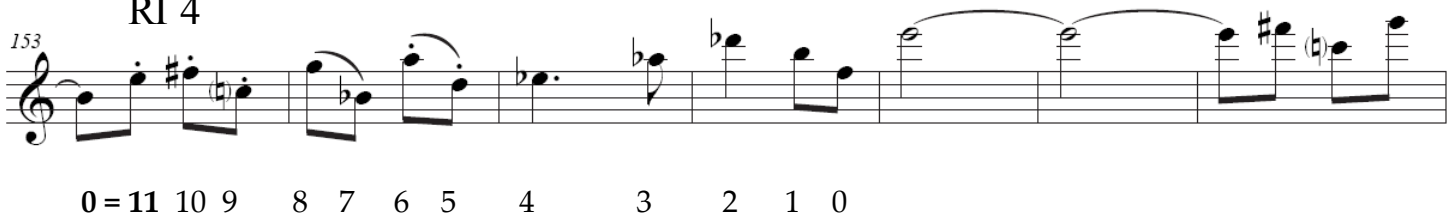

Exemplo 6: Elisão da série no compasso 153 entre séries RI-3 e RI-4 (parte da flauta)

\subsection{Substituição}

Ocorre quando há troca de um elemento da série por outro não adjacente.

\begin{tabular}{|c|c|c|c|c|c|}
\hline mov & compasso & série & nota trocada & justificativa & observação \\
\hline $2^{\circ}$ mov & 131 & R9 & 5 por 2 & motivo rítmico do acompanhamento & trocou o Si pelo Dó \\
\hline $3^{\text {o }}$ mov & 211 & R9 & 2 & figura em uníssono termina com $7 \mathrm{M}$ & interrompe o discurso \\
\hline
\end{tabular}

Tabela 4: Substituições na série nos três movimentos da Sona ta para flauta

Este tipo de procedimento pode ser considerado praticamente ausente na Sonata para flauta. No segundo movimento é usado como parte de um motivo rítmico do acompanhamento na mão esquerda do piano (uma figura semelhante com inversão ocorre um compasso depois).

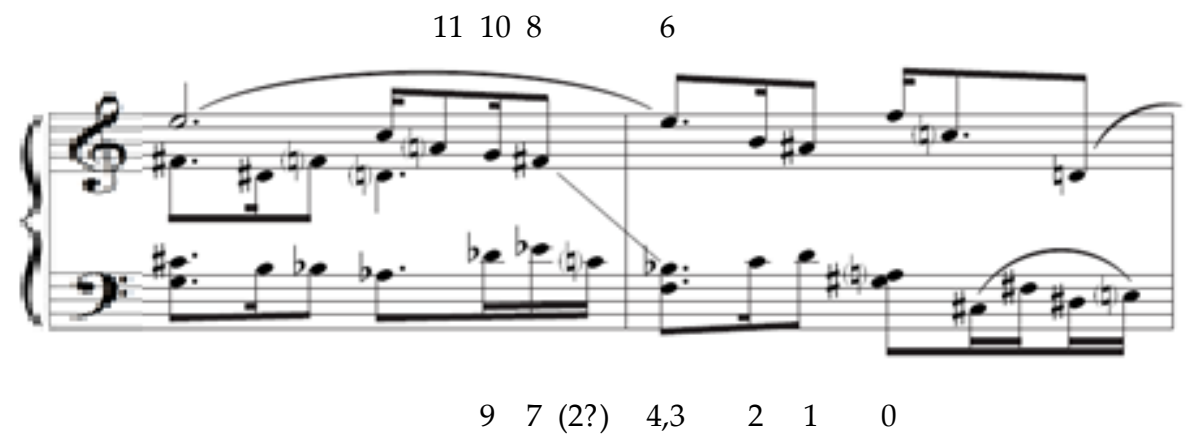

Exemplo 7: Substituição de nota da série no compasso 131 


\subsection{Permuta}

Ocorre quando há troca entre dois membros adjacentes da série. Este artifício é convencional e frequentemente encontrado nas obras de Schoenberg.

\begin{tabular}{|c|c|c|c|c|c|}
\hline mov. & comp. & série & ordem & justificativa & observação \\
\hline $1^{\mathrm{o}} \mathrm{mov}$ & 1 e 75 & 010 & 9 por 10 & usar intervalo de $2 \mathrm{~m} / 7 \mathrm{M}$ & série horizontal, no piano \\
\hline $1^{\mathrm{o}} \mathrm{mov}$ & 68 & O6 & 9 por 10 & usar intervalo de $2 \mathrm{~m} / 7 \mathrm{M}$ & série horizontal na flauta \\
\hline $1^{\mathrm{o}} \mathrm{mov}$ & 87 & I10 & 6 por 7 & fazer o motivo mib, ré, dó & série horizontal \\
\hline $1^{\mathrm{o}} \mathrm{mov}$ & 94 & I10 & 6 por 7 & fazer o motivo mib, ré, dó & série horizontal \\
\hline $1^{\mathrm{o}} \mathrm{mov}$ & 111 & O1 & 5 por 6 & circularidade do motivo & série horizontal na flauta \\
\hline $1^{\mathrm{o}} \mathrm{mov}$ & 113 & O1 & 5 por 6 & piano repete flauta no 111 & série horizontal na flauta \\
\hline $3^{\circ} \mathrm{mov}$ & 160 & RI5 & 5 por 6 & motivo ascendente & polifonia no piano \\
\hline $3^{\circ} \mathrm{mov}$ & 163 & RI5 & 5 por 6 & usar cromatismo & polifonia no piano \\
\hline $3^{\mathrm{o}} \mathrm{mov}$ & 166 & RI5 & 4 por 5 & motivo - salto entre vozes & polifonia no piano \\
\hline $3^{\circ} \mathrm{mov}$ & 168 & RI5 & 6 pelo 7 & lineariedade da voz & polifonia no piano \\
\hline $3^{\mathrm{o}} \mathrm{mov}$ & 169 & RI5 & 1 pelo 2 & salto de terça entre vozes & polifonia no piano \\
\hline $3^{\circ} \mathrm{mov}$ & 169 & RI5 & $8,11,10,9,7$ & movimento das vozes & polifonia no piano \\
\hline $3^{\circ} \mathrm{mov}$ & 176 & RI8 & 4 e $5 ; 2$ e 3 & linha descendente & polifonia no piano \\
\hline $3^{\mathrm{o}} \mathrm{mov}$ & 241 & RI3 & $2,1,0$ & movimento das vozes & polifonia no piano \\
\hline $3^{\mathrm{o}} \mathrm{mov}$ & 244 & RI3 & $11,8,9,7,10$ & motivo rítmico & série horizontal, no piano \\
\hline $3^{\circ} \mathrm{mov}$ & 245 & RI3 & $6,5,4,0,1,3,2$ & inversão da figura de 244 & série horizontal, no piano \\
\hline
\end{tabular}

Tabela 4: Substituições na série nos três movimentos da Sonata para flauta

O uso das permutas no primeiro movimento permite a utilização de motivos com intervalos de segunda menor ou de motivos com tons descendentes, ampliando assim as similaridades no discurso musical. Este método é coerente com a linguagem barroca adotada na peça. As permutas na parte polifônica do terceiro movimento, entre as vozes do piano, visam estimular e enriquecer a variedade de ritmos e de sequências de intervalos usados no contraponto.

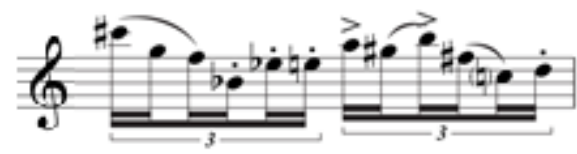

Exemplo 8: Permuta usando uma figura circular no compasso 111 (parte da flauta)

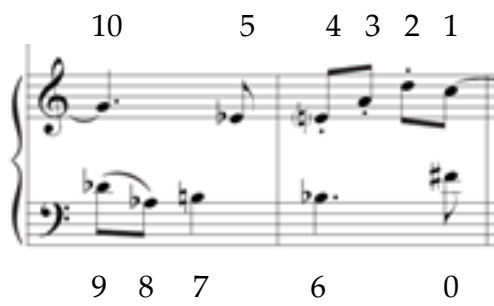

Exemplo 9: Permuta no compasso 163 (parte do piano) Intervalos cromáticos entre 7 e 6 , assim como entre 5 e 4

\section{MUSICA THEORICA}




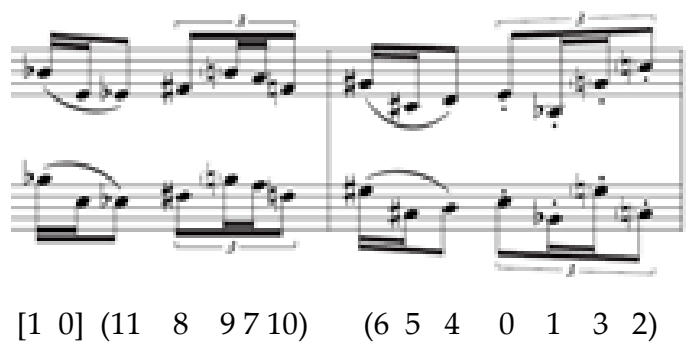

Exemplo 10: Permuta nos compassos 244 e 245 (parte do piano) -

No compasso 245 ocorre uma inversão do motivo do compasso 244

\subsection{Inserção}

Ocorre quando há inclusão de um som estranho à ordem da série. A inserção é usada como elemento transformador do material melódico, usando saltos em intervalos diferentes, nas repetições de motivos musicais.

\begin{tabular}{|c|c|c|c|c|c|}
\hline mov. & comp. & série & ordem & justificativa & observação \\
\hline $1^{\mathrm{o}} \mathrm{mov}$ & 40 & O7 & $11+0$ & transformar motivo & motivo termina $\mathrm{c} /$ salto de $1 / 2$ tom \\
\hline $1^{\circ} \operatorname{mov}$ & 44 & O9 & $11=2$ & transformar motivo & substituição em série de outra voz \\
\hline $1^{\mathrm{o}} \mathrm{mov}$ & 47 & O9 & $11+5$ & transformar motivo & motivo termina com salto de $3 \mathrm{M}$ \\
\hline $1^{\circ} \mathrm{mov}$ & 69 & O6 & 0 & prenúncio da reprise & poderia ser também repetição \\
\hline $1^{\mathrm{o}} \mathrm{mov}$ & 97 & I6 & $0,1,2,4$ & acorde formado por $7 \underline{a s}$ & - \\
\hline $1^{\mathrm{o}} \mathrm{mov}$ & 103 & I10 & {$[3,5,7,11]$} & - & imitação da figura, piano do comp. anterior \\
\hline $1^{\mathrm{o}} \mathrm{mov}$ & 107 & $\mathbf{I 1 0}$ & 0 & manter intervalo de $7 \mathrm{M}$ & transforma figura do compasso anterior \\
\hline $2^{\mathrm{o}} \mathrm{mov}$ & 121 & R7 & $+(1,0,4)$ & - & figuração do baixo: manter ritmo de siciliana \\
\hline $2^{\circ} \mathrm{mov}$ & $132 / 133$ & R9 & $5-1$ & - & exceção: manter o ritmo de siciliana \\
\hline $3^{\mathrm{o}} \mathrm{mov}$ & 169 & RI5 & 11 & completa compasso 166 & manter diálogo rítmico no piano \\
\hline $3^{\mathrm{o}} \mathrm{mov}$ & $244 / 246$ & RI4 & $+3,+2$ & - & - \\
\hline $3^{\circ} \mathrm{mov}$ & 253 & $3 \times \mathrm{RI} 4$ & $5+$ & - & interrupção da cadência pela nota estranha \\
\hline
\end{tabular}

Tabela 5: Inserções na série nos três movimentos da Sonata para flauta

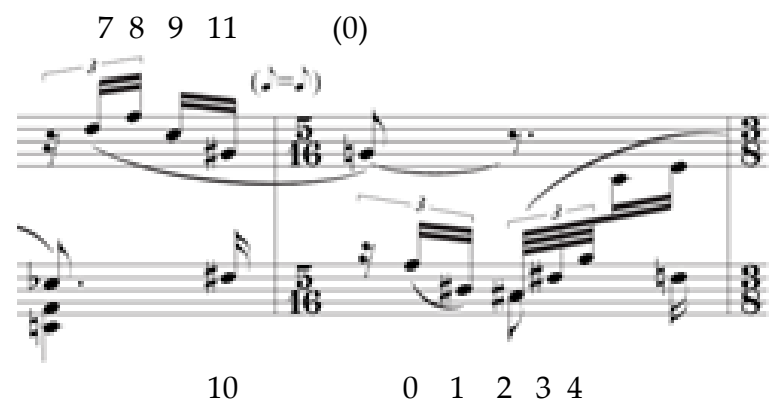

Exemplo 11: Inserção no compasso 40 - [O7]: troca entre 11 e 0 , intervalo de 1/2 tom 


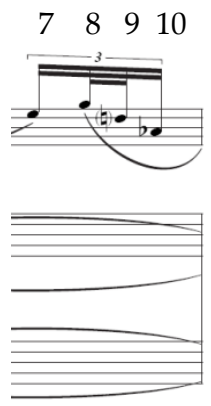

(2) 45

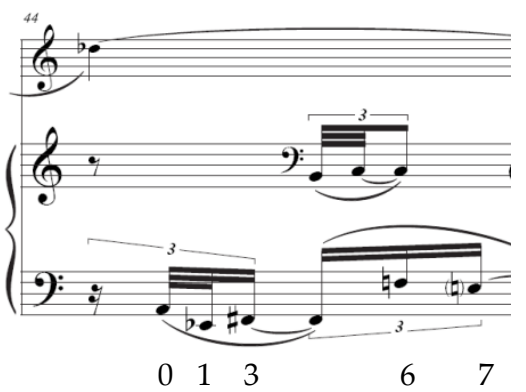

Exemplo 12: Inserção no compasso 44 - [O9]: troca entre 11 e 2 , intervalo de 4 justa

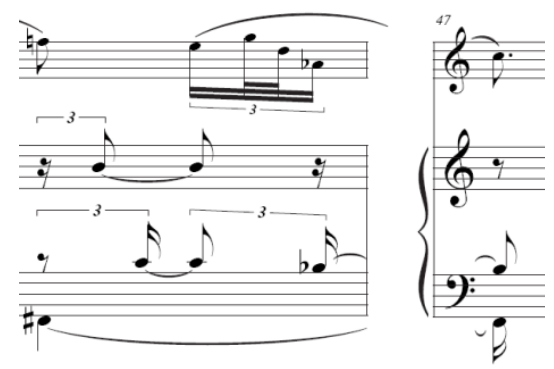

11

Exemplo 13: Inserção no compasso 47 - [O9]: troca entre 11 e 5, intervalo de 3M

Outro caso de uso da inserção que vale a ser destacado, quando um motivo inteiro imita outra voz.

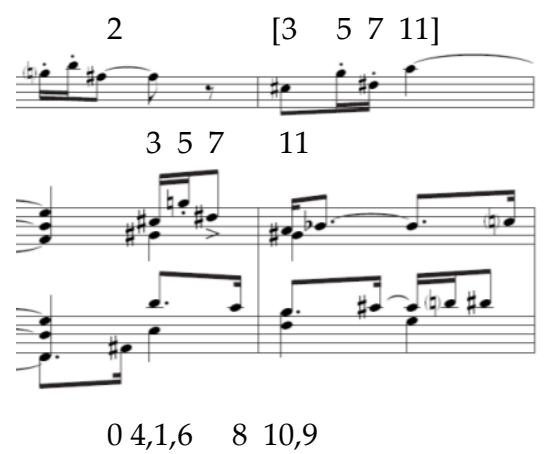

Exemplo 14: Inserção no compasso 103 - [I10]

\subsection{Omissão}

Ocorre quando há ausência de um membro da série sem nenhuma substituição ou troca. Pode ser considerado um procedimento não-convencional mas tem precedentes em obras de outros dodecafonistas, mesmo em Schoenberg. 


\begin{tabular}{|c|c|c|c|c|c|}
\hline mov. & comp. & série & ordem & justificativa & observação \\
\hline $1^{\circ} \mathrm{mov}$ & 36 & O7 & 4 & ordem invertida & possível relação de hexacordes \\
\hline $1^{\mathrm{o}} \mathrm{mov}$ & 38 & O7 & $2,6,10,11$ & - & transparência do diálogo do motivo nas vozes \\
\hline $1^{\mathrm{o}} \mathrm{mov}$ & 60 & $\mathrm{O4}$ & 3 & - & imitação da figura na flauta motiva a omissão \\
\hline $1^{\mathrm{o}} \mathrm{mov}$ & 90 & I10 & 9 & nota fá quebra o acorde & $7,6,8$ usa sétimas na harmonia, razão vertical \\
\hline $1^{\mathrm{o}} \mathrm{mov}$ & 99 & I7 & 11 & - & construção harmônica \\
\hline $1^{\mathrm{o}} \mathrm{mov}$ & 105 & I10 & $9(f a ́)$ & uso de 5 s e 6 s, vertical & construção harmônica \\
\hline $1^{\mathrm{o}} \mathrm{mov}$ & 113 & O1 & 9,10 & repetiu 5 , pulou 9 e 10 & movimento cadencial para terminar \\
\hline $2^{\circ} \mathrm{mov}$ & 132 & R9 & 10 & - & cria diversidade rítmica entre as vozes \\
\hline $3^{\mathrm{o}} \mathrm{mov}$ & 165 & RI5 & 11 & - & cria polifonia sincopada entre as vozes \\
\hline $3^{\circ} \mathrm{mov}$ & 166 & RI5 & 11 & - & cria polifonia sincopada entre as vozes \\
\hline $3^{\mathrm{o}} \mathrm{mov}$ & 171 & RI5 & 5 & polifonia, horizontal & manter diálogo de saltos entre as vozes \\
\hline $3^{\mathrm{o}} \mathrm{mov}$ & 173 & RI6 & 5 & polifonia, horizontal & manter diálogo de saltos entre as vozes \\
\hline $3^{\circ} \mathrm{mov}$ & 201 & R9 & 6 & - & transparência do ritmo da siciliana \\
\hline $3^{\mathrm{o}} \mathrm{mov}$ & 227 & RI3 & 9 & importante omissão! & manter diálogo, pequenos intervalos nas vozes \\
\hline $3^{\circ} \mathrm{mov}$ & 231 & RI3 & 4 & polifonia, horizontal & diálogo entre as vozes \\
\hline $3^{\mathrm{o}} \mathrm{mov}$ & 238 & RI4 & $2,1 ?$ & polifonia, horizontal & manter a figura rítmica \\
\hline $3^{\mathrm{o}} \mathrm{mov}$ & 242 & RI3 & 2 & polifonia, horizontal & - \\
\hline $3^{\mathrm{o}} \mathrm{mov}$ & 243 & RI3 & 11,10 & - & diálogo com a flauta \\
\hline $3^{\circ} \mathrm{mov}$ & 249 & RI5 & 4 & vertical & - \\
\hline $3^{\circ} \mathrm{mov}$ & 252 & RI7 & 8,0 & 0 aparece no comp. 254 & - \\
\hline $3^{\circ} \mathrm{mov}$ & 256 & RI7 & 1,0 & final da obra & - \\
\hline
\end{tabular}

Tabela 6: Omissões na série nos três movimentos da Sonata para flauta

Este recurso é frequentemente utilizado por Santoro na Sonata e pode ser dividido entre duas formas básicas de utilização.

A) Omissões da série usada em seu modo horizontal.

No $3^{\mathbf{o}}$ movimento Santoro usa as omissões visando criar diversidade rítmica e motívica entre as vozes. Outra utilização é a imitação de uma figura entre o piano e a flauta, como no Exemplo 15.

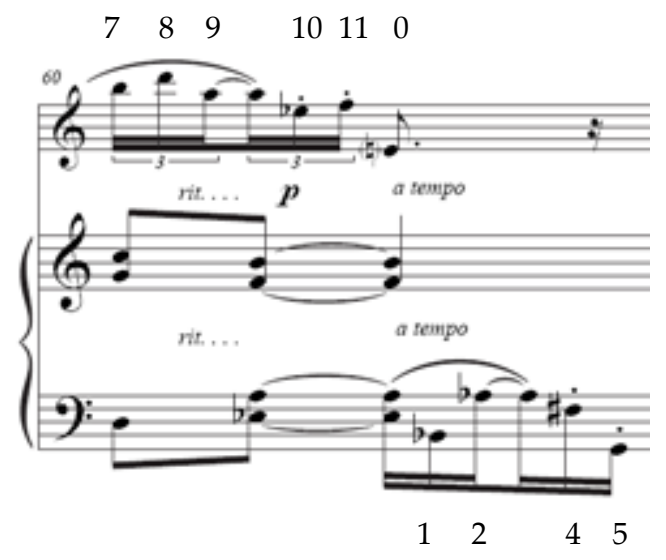

Exemplo 15: Omissão da 3ª nota da série 
B) Omissões da série em seu modo vertical.

As omissões ocorrem quando acordes são formados por intervalos específicos, como por exemplo, acordes com intervalos de sétimas ou acordes formados por intervalos de quintas e ou sextas, entre outras possibilidades verificadas. A inclusão destas notas omitidas impossibilitaria a formação destes intervalos. Santoro utiliza também a permuta entre as notas do acorde, visando claramente construir acordes com intervalos determinados.

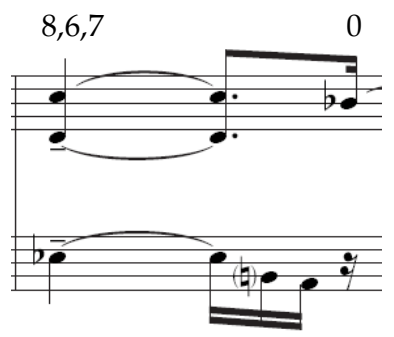

1011

Exemplo 16: compasso 90, (acorde formado por sétimas omite o fá [9 da série])

Estas análises são endossadas pelo que Cláudio Santoro falou posteriormente, em 1976, a respeito de formações de clusters e intervalos, técnica que já usava espontaneamente:

Eu estou fazendo certos estudos principalmente com eletroacústica, que são mais fáceis de você fazer, mesmo no piano. Coisas que eu fiz em 1941, o Quarteto no 1, por exemplo, já tem cluster, em que lá era uma coisa mais espontânea do que hoje que tenho a experiência e uso isso com um conhecimento da coisa em si, um métier [...] Então eu cheguei a essa conclusão: quando você usa um acorde baseado em terças ou em quartas, você pode ser muito mais dissonante do que quando você usa um acorde ou um conjunto de sons, onde os sons de combinação se alteram e se eliminam entre si. Cheguei a essa conclusão. As ondas sonoras, as vibrações sonoras de um conjunto de sons mais perto, como por exemplo as segundas menores, no fundo vão soar mais consonantem ente do que se você fizer um acorde. Eu faço sempreexperiências com os alunos: fazemos um cluster e comparamos com um acorde depois. O cluster soa muito mais consonante. Então eu mando cada um cantar - dó, dó\#, ré, ré\#, mi e fá. Parece um absurdo, mas você pega cada um cantando, os sons de combinação se eliminam e dão um outro timbre harmônico que parece um som só. Ele passa a não ser mais um acorde, mas sim um som novo muito mais consonante do que se você fizer um acorde- dó, mib, solb, si, ré e mi - que não é um cluster, é um acorde. Soa muito mais dissonante, muito mais agressivo do que se você fizer este cluster. Eu cheguei à conclusão de uma eliminação acústica dos sons de combinação. Eu não pude ainda provar isso acusticamente, por meios eletroacústicos poderia provar isso. Mas eu tenho quase certeza que isso se dá, porque eu ouço isso. E sabe, a teoria em geral, vem a se confirmar depois de uma experiência. Você cria um determinado elemento e depois você dá uma explicação. O mesmo na física, eu convivo muito com físicos.

\section{MUSICA THEORICA}


Se deu um fato muito engraçado, conversando sobre esse assunto com meu irmão, eu queria que ele testasse isso para mim através do computador, ou através de aparelhos ou como se pudesse testar isso, se realmente essas ondas eram eliminadas ou não. E através dessa minha ideia ele descobriu um negócio novo na física: eliminação das ondas. Ele telefonou para mim e disse sobre as ondas que são eliminadas, dizendo que na física tem um programa que ele tinha a impressão de que também acontecia isso. Então ele fez os cálculos e acabou provando que o negócio é assim mesmo. Já deve também outras pessoas ter pensado nisso e ter falado sobre esse assunto, eu não sei, eu nunca vi outras pessoas falando sobre esse assunto. Mas então são novas densidades, não timbres, mas densidades sonoras que criam outros critérios na utilização dos sons (Santoro 1976).

\subsection{Séries incompletas}

Séries incompletas aparecem na Sonata para flauta principalmente em finais de movimento ou finais de seção, indicando que Santoro entendia que a série e o princípio serial deviam ser usados como fonte gerativa de materiais discursivos e não como uma imposição de repetições mecânicas da série.

\begin{tabular}{|c|c|c|c|c|c|}
\hline mov. & comp. & série & ordem & justificativa & observação \\
\hline $1^{\mathrm{o}} \mathrm{mov}$ & 50 & O1 & falta $7-11$ & fim da parte A do Lento & tem ritardando \\
\hline $1^{\mathrm{o}} \mathrm{mov}$ & 58 & $\mathrm{O} 4$ & falta $4-11$ & pausa interrompe discurso & piano repete em diminuição \\
\hline $1^{\mathrm{o}} \mathrm{mov}$ & 104 & I10 & falta $0-6$ & conclusão da imitação do c.103 & - \\
\hline $2^{\circ} \mathrm{mov}$ & 138 & R6 & falta 5-0 & fim do 2. mov & fermata, suspensão \\
\hline $3^{\circ} \mathrm{mov}$ & 250 & RI6 & falta 3-0 & - & stretto, modulação da série \\
\hline $3^{\mathrm{o}} \mathrm{mov}$ & 251 & RI7 & falta 11-8 & - & stretto, modulação da série \\
\hline $3^{\circ} \mathrm{mov}$ & 255 & RI4 & falta $7-0$ & - & - \\
\hline $3^{\circ} \mathrm{mov}$ & 258 & RI4 & falta $4-0$ & fim da obra & início do tema como conclusão \\
\hline
\end{tabular}

Tabela 7: Séries incompletas nos três movimentos da Sonata para flauta

Mendes $^{29}$ também reconhece que as séries incompletas são usadas com mais frequência na conclusão de partes, seções e finais de movimentos, assim como interrupções da frase ou do diálogo musical. Notamos que esse recurso também é usado para a construção do clímax musical na conclusão do terceiro movimento, utilizando fragmentos da série para criar diálogos cada vez mais sobrepostos entre a flauta e o piano. Anos mais tarde, na composição do Sexto Quarteto de Cordas empregará o mesmo recurso para obter efeito semelhante (Coelho de Souza 2012), o que demonstra que Santoro incorporou esse artifício

\footnotetext{
${ }^{29}$ Mendes, Sérgio Nogueira. 2009. O Percurso estilístico de Claudio Santoro, roteiros divergentes e conjução final, Doutorado, UNICAMP.
} 
como técnica idiomática de sua linguagem musical, independentemente do período em que a obra estivesse sendo escrita.

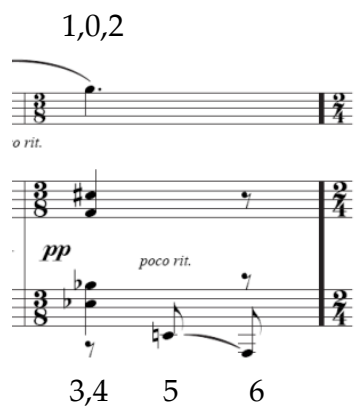

Exemplo 17: compasso 50, final do Lento do 1o movimento - série O1 incompleta [0 a 6]

A série incompleta no Exemplo 18 é usada como interrupção do discurso musical. A figura do piano é uma diminuitio do motivo na flauta em uníssono.

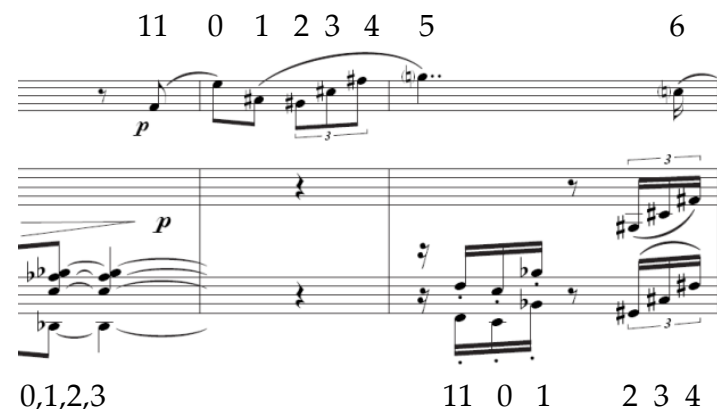

Exemplo 18: compasso 58, omissão de partes da série

\subsection{Uso da série parcialmente transposta}

Em alguns momentos da Sonata para flauta Santoro transpõe partes da série, acreditamos que por motivos de desenvolvimento do discurso musical.

A sequência virtuosística da flauta no final da Sonata, traz um exemplo interessante do uso de uma parte da série transposta meio tom acima, com o intuito de exaltar e desenvolver um contorno melódico irregular, usando a transposição para criar um clímax crescente na frase. Interessante também é o uso da inserção do (5) para interromper a repetição do desenvolvimento da frase.

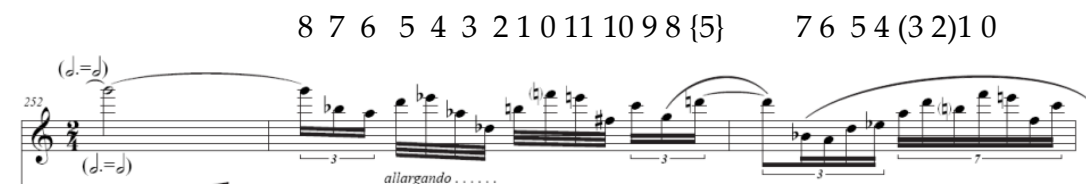

Exemplo 19: compasso 254, parte da flauta; sequência de [RI4], com $(3,2)$ como [RI5] 
Outra manipulação significativa ocorre no compasso 133. A fim de obter a imitação de uma figura da flauta e criar uma interrupção no diálogo pelo piano, Santoro transpõe o final da série.

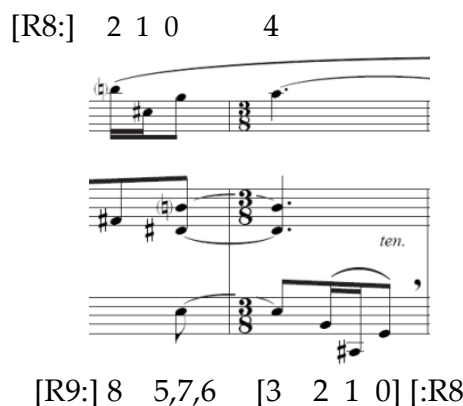

Exemplo 20: compasso 133 - [R8] na flauta, [R9] no piano;

O final (3-0) da série no piano pertence a [R8]

Antes do compasso 215, o motivo entre as vozes se desfaz literalmente, criando um stretto entre as vozes. Aqui Santoro usa o artifício da transposição para preparar retoricamente a fermata, transformando o material musical em uma espécie de figura interrogativa.
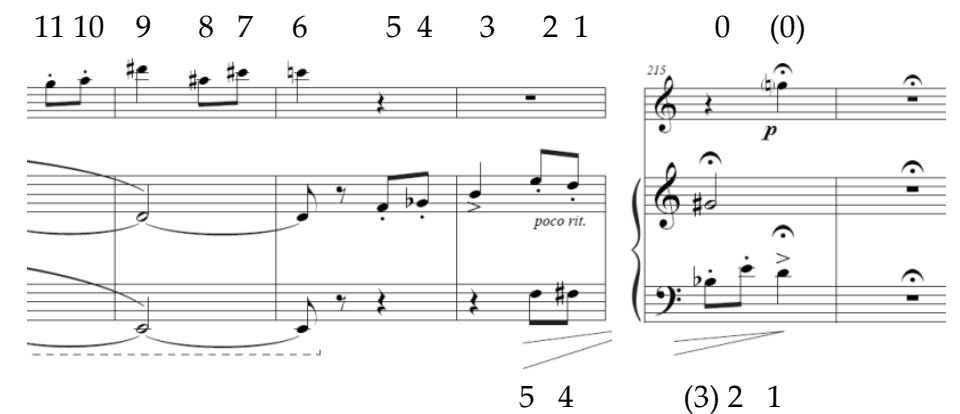

Exemplo 21: compasso 215, transposição $1 / 2$ tom abaixo de $(3,0)$ da série

Existem ainda outras ocorrências, como no compasso 87 na parte da flauta, onde as últimas três notas $(9,10$ e 11) da série [I11] são transpostas para [15] e também no compasso 247, onde na série RI4 as notas 11 até 8 são transpostas para RI10. Como se vê são alterações locais, ou do ordenamento serial, ou da transposição da série, que não alteram a coerência do pensamento serial, apenas demonstram uma flexibilidade no seu emprego para produzir certos efeitos retóricos projetados pelo compositor. 


\subsection{Divisão da série dodecafônica em dois hexacordes independentes}

Sabemos hoje que a divisão da série em dois hexacordes independentes fez parte importante da gênese do sistema dodecafônico e continuou a fazer parte das técnicas que Schoenberg empregava em suas composições maduras. Santoro dificilmente poderia ter sabido disso na época da composição da Sonata para flauta, a menos que tivesse chegado à sua mão alguma obra de Schoenberg para ser usada como modelo. Todavia não há nenhuma evidência de que isso tenha ocorrido. Não seria surpresa, portanto, que essa técnica não ocorresse na Sonata. A surpresa, ao contrário, é que a divisão da série em dois hexacordes ${ }^{30}$ pode ser verificada na Sonata para flauta, embora somente em algumas raras passagens. $\mathrm{O}$ uso desse artifício parece ser evocado para flexibilizar a transformação dos intervalos de algum motivo temático.

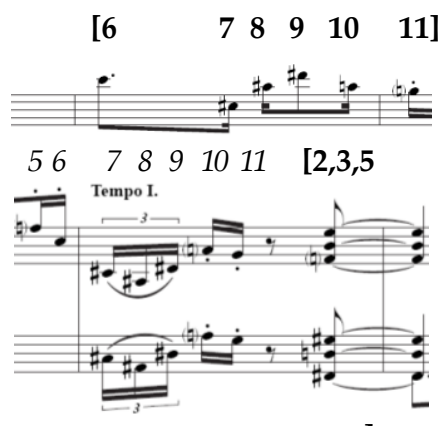

$0,1,4]$

Exemplo 22: Compasso 101, divisão da série em dois hexacordes independentes

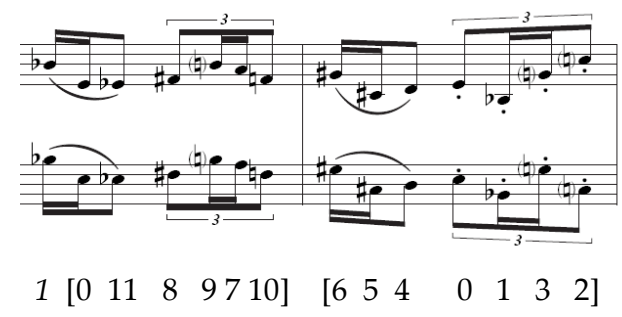

Exemplo 23: Compassos 244 e 245, parte do piano

Divisão da série em dois hexacordes reordenados (técnica de tropos de Schoenberg)

\section{5 - Considerações sobre o Processo Genético da Sonata}

Um dos trechos mais intrigantes para a análise da consistência dodecafônica da obra ocorre no primeiro movimento quando o tema apresentado

\footnotetext{
30 Ocorre nos compassos 16, 101 (Exemplo 22), 120 e 244-245 (Exemplo 23). No compasso 169, essa seria uma inter pretação possível, mas não a única. No compasso 35 haveria uma combinação de artifícios (a série aparece dividida como [3,5,6,8,4] + [0,1,2,8,11,9,7]).
} 
pelo piano é repetido integralmente pela flauta, criando uma série de inserções e repetições aparentemente sem nexo para a contagem da série dodecafônica.

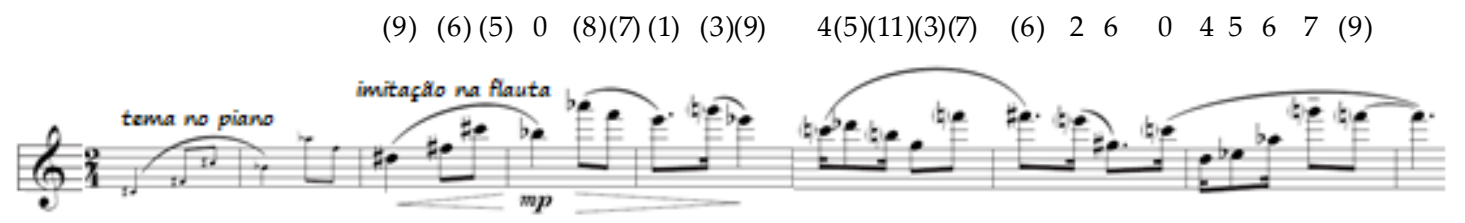

Exemplo 24: Tema na flauta que repete o material apresentado pelo piano logo antes. As notas com parênteses são inserções e/ou repetições de notas da série.

Um relato de Santoro sobre seu processo criativo, embora de data muito posterior à composição da Sonata, ajuda a esclarecer aquela passagem intrigante.

Em todas as minhas obras dodecafônicas eu primeiro criava o tema, depois do tema é que eu tirava o material sonoro, fazia a minha série que às vezes era completa e quando era incompleta eu completava, para depois utilizar. Quero dizer então, a obra ficava muito diferente do que se fazia antes e do que se fazia depois. Os compositores primeiro escreviam o material, criavam o material, e do material criavam a obra. Por isso que muitas obras dessa época, e principalmente depois no serialismo integral, são obras que não dizem nada. Você fica intelectualmente achando interessante, mas a arte tem algo mais do que o simples prazer intelectual. É claro que a arte sem organização do material também nãoé uma obra de arte. Uma obra musical, ela tem que ter a organização dos seus sentimentos ${ }^{31}$ (Santoro 1986).

Entendemos então que o tema, propriamente dito, é o material que aparece nos compassos 5-6, no piano, e a seguir é imitado pela flauta (ver Exemplo 1). A série dodecafônica usada ao longo da obra é derivada desse tema livremente composto, sendo completada com as alturas que faltavam. Esse material adicional aparece então como uma introdução, nos compassos 1 a 4 . Esse procedimento se coaduna com nossa hipótese de que a gênese da obra está ligada a um impulso intertextual com a música barroca. $\mathrm{O}$ impulso inicial teria sido um processo imitativo caracteristicamente barroco, que é a seguir elaborado com a técnica dodecafônica como meio de gerar um procedimento contrapontístico modernista, e evitando um possível ranço neoclássico.

\section{6 - Arquitetura Formal dos Movimentos}

Para introduzir o problema da forma, elaboramos gráficos que mostram como Santoro usou as séries nos modos horizontal e vertical em cada movimento.

31 Santoro 1986. Contando minha vida. 
Nossa análise observou que, para Santoro, a concepção de forma, em obras compostas com a técnica dodecafônica, está intrinsicamente ligada à escolha e combinação das séries utilizadas. O mesmo ocorre nas obras referenciais dos compositores da Segunda Escola de Viena. Essa coincidência pode ser resultado da intuição do compositor ou então da análise dessas obras referenciais. Seja como for, é admirável que Santoro tenha concebido suas formas dessa maneira.

No primeiro movimento, as características formais são típicas de uma Trio Sonata barroca, onde as duas vozes superiores (dessus) são divididas no diálogo entre a flauta e o piano, enquanto a linha do baixo tem a função de baixo contínuo.

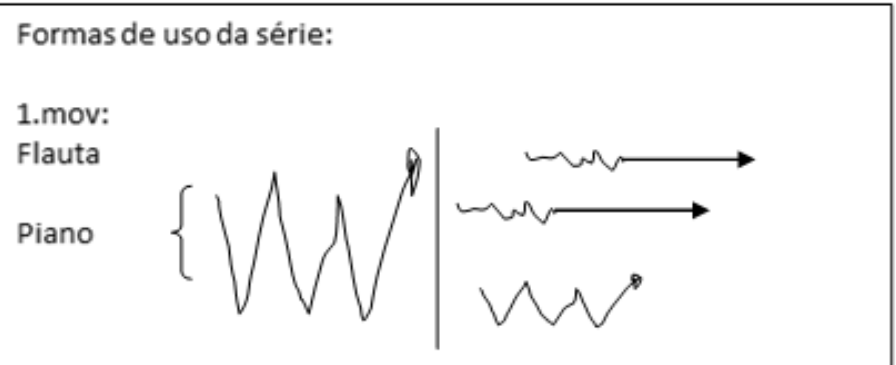

Tabela 8: Esquema gráfico da forma do primeiro movimento

No segundo movimento, a flauta tem a função melódica (série horizontal) enquanto o piano tem apenas a função de acompanhamento, criando células da série em modo vertical.

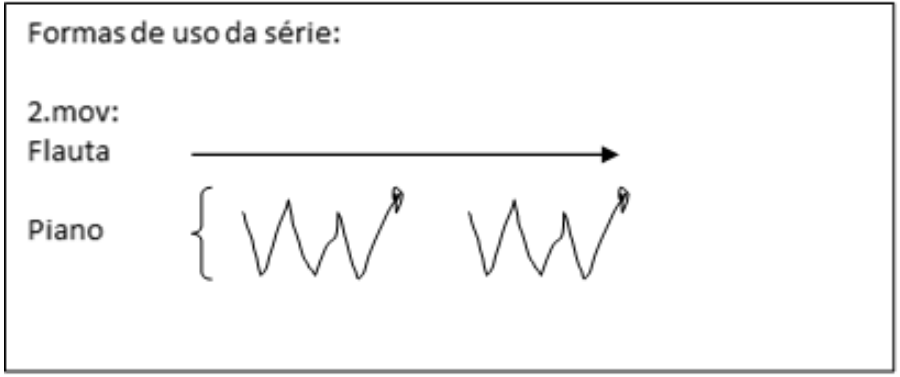

Tabela 9: Esquema gráfico da forma do segundo movimento

No terceiro e último movimento, a construção é polifônica, como nas peças de consort, onde cada voz usa independentemente a série no seu modo horizontal.

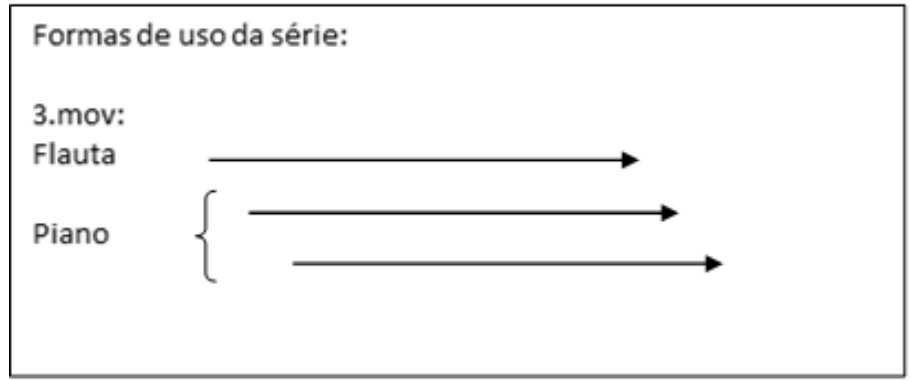

Tabela 10: Esquema gráfico da forma do terceiro movimento

\section{MUSICA THEORICA}


A seguir elaboramos a análise das particularidades de construção de cada movimento.

\subsection{Primeiro movimento}

A Sonata se inicia com um Lento onde uma pequena introdução no piano introduz a série. Na parte A, o tema da flauta aparece em forma de uma resposta canônica ao tema dado pelo piano. Mais adiante, uma pequena cadência na flauta prepara um novo episódio musical - no compasso 25, aparece, na parte do piano, um trecho invertido do tema. No final da parte A, o diálogo entre o piano e a flauta se torna cada vez mais complexo no ritmo e nos intervalos, terminando em figuras de suspiro na flauta.

O Allegretto da parte B se inicia com figuras de semicolcheias cheias de interrupções e acentos musicais no piano. As séries se desenvolvem no diálogo entre a flauta e o piano no melhor espírito do discurso barroco (ver Exemplo 18).

A flauta utiliza exclusivamente a série (O4 e O6) em modo horizontal, melódico, sem qualquer tipo de alteração. Incide uma reprise encurtada, seguida da volta do Allegretto, usando agora a série de forma invertida. O discurso se torna cada vez mais complexo, até chegar à Coda, onde o tema do Allegretto reaparece em sua forma original concluindo a peça em fortíssimo.

\subsubsection{Sequência de modulações da série}

A sequência de séries utilizadas demonstra uma construção que visa criar uma percepção de gradação contínua de tensão, através da sucessiva modulação da série por intervalos de tom inteiro ascendeste. No retorno do Tempo I, quando a inversão da série é modulada por intervalos de $1 / 2$ tons ascendentes, Santoro já utilizou a série em 11 alturas diferentes. A série que falta aparece apenas na conclusão do movimento. Santoro aproxima-se, usando a série invertida, duas vezes da série [I10] através de gradações de $1 / 2$ tons, dando uma sensação de chegar a um "ponto de órgão" na dominante, para finalmente encerrar $o$ movimento no [O3], criando a sensação de resolução por complementação. Portanto, não só a série usada tem doze notas, como todas as doze transposições possíveis da série são usadas. 


\begin{tabular}{|c|c|c|c|c|c|c|c|c|c|c|c|c|c|}
\hline & \multicolumn{9}{|c|}{ Lento } & \multicolumn{2}{|c|}{ Allegretto } & \multicolumn{2}{|c|}{ Lento reprise } \\
\hline nota & lab & sib & dó & ré & fá & sol & lá & si & dó\# & $\mathrm{mi}$ & fa\# & sol\# & sib \\
\hline série & 08 & O10 & O0 & $\mathrm{O} 2$ & O5 & O7 & 09 & 011 & O1 & 04 & 06 & 08 & 010 \\
\hline modula & \multicolumn{4}{|c|}{$1 \mathrm{Tom}$} & \multicolumn{5}{|c|}{$1 \mathrm{Tom}$} & \multicolumn{2}{|c|}{1 Tom } & \multicolumn{2}{|c|}{1 Tom } \\
\hline
\end{tabular}

\begin{tabular}{|c|c|c|c|c|c|c|c|c|c|c|}
\hline & \multicolumn{10}{|c|}{ Tempo I } \\
\hline nota & $\mathrm{mi}$ & fá & sib & fa\# & sol & sol\# & sib & $\mathrm{mi}$ & dó\# & mib \\
\hline série & I4 & I5 & I10 & I6 & I7 & I8 & I10 & O4 & O1 & O3 \\
\hline \multirow{2}{*}{$\begin{array}{l}\text { número de } \\
\text { ocorrências }\end{array}$} & $3 x$ & $5 x$ & $11 x$ & $1 x$ & $3 x$ & $2 x$ & $7 x$ & $2 x$ & $2 x$ & $1 x$ \\
\hline & \multicolumn{2}{|c|}{$8 x$} & & \multicolumn{3}{|c|}{$6 x$} & & \multicolumn{2}{|c|}{$4 x$} & \\
\hline modula & \multicolumn{2}{|c|}{$12 \mathrm{Tom}$} & $\mathrm{V}$ & & $2 \mathrm{Tol}$ & & $\mathrm{V}$ & & & I \\
\hline
\end{tabular}

\subsection{Segundo movimento}

É um Andante em forma de Siciliana com figuras rítmicas típicas do séc. XVIII no acompanhamento, enquanto a flauta executa a melodia. A figura de suspiro, outra figura típica do barroco, aparece no segundo movimento potencializada pelo seu uso em tempos fracos do compasso. A série é usada na flauta por três vezes sem alterações.

\subsubsection{Sequência de modulações da série}

\begin{tabular}{|c|c|c|c|c|c|c|c|}
\hline Flauta & R5 & R5 & \multicolumn{2}{|c|}{ R8 } & - & melodia & horizontal \\
\hline Piano & R5 & R7 & R9 & R8 & R6 & a companhamento & vertical \\
\hline \multirow{3}{*}{$\begin{array}{l}\text { número de } \\
\text { ocorrências }\end{array}$} & $7 x$ & $7 x$ & $6 x$ & $1 x$ & $3 x$ & & \\
\hline & fá & sol & lá & sol\# & $\mathrm{fa} \#$ & & \\
\hline & \multicolumn{3}{|c|}{1 tom a cima } & \multicolumn{2}{|c|}{1 tom abaixo } & & \\
\hline
\end{tabular}

O tema na flauta usa a série retrógada [R5] em duração de 7 compassos, com a série na horizontal, enquanto o acompanhamento faz a série em modo vertical em ritmo de siciliana, modulando de tom em tom a cada 7 repetições (ou compassos). O tema reaparece cada vez com uma modulação da série no piano, com exceção das últimas 3 intervenções da série do piano.

\subsection{Terceiro movimento}

Podemos salientar algumas das características barrocas do terceiro movimento: tema canônico, fermata, cadência, uníssono, tema em aumentação, entre outras. Particularidade do tema fugato: o Canon é melódico, mas não rítmico. Vozes entram no mesmo tom (canon em oitava), sempre com surpreendente variação rítmica para cada nova intervenção do tema. 


\subsubsection{Parte A}

As 3 vozes usam a série retrógada invertida [RI3] pela primeira vez e de forma linear por 20 compassos, antes das vozes do piano começarem a dividir a série entre si. As vozes se dissolvem no final da seção, com a parte do piano se transformando em acompanhamento, preparando a parte B (transição já comentada no item "séries incompletas").

\subsubsection{Parte B}

A parte B inicia usando a série retrógada [R5] em uníssono, em dupla aumentação, dando a sensação de uma parte mais lenta, como se fosse um cantus firmus. A flauta cita o tema da Siciliana com grandes interrupções e valores rítmicos mais lentos. A parte B se encerra com citações em stretto do tema da parte A, culminando em uma fermata interrogativa e uma generalpause (transição comentada no item "séries transpostas").

\subsubsection{Retorno da Parte A}

Nesta reprise, a segunda voz introduz o tema (ou seja, a série) em transposição $1 / 2$ tom acima e em aumentação, enquanto as outras vozes continuam no tom original da série. O ponto culminante da obra usa várias séries incompletas, intensificando o stretto, culminando em uma cadência virtuosa da flauta que cria uma sensação de acelerando. A seção é concluída com um fragmento do tema A em uníssono.

\subsubsection{Sequência de modulações da série}

\begin{tabular}{|c|c|c|c|c|c|c|c|}
\hline \multicolumn{5}{|c|}{ parte A } & \multicolumn{3}{c|}{ parte B } \\
\hline RI3 & RI4 & RI5 & RI6 & RI8 & R5 & R9 & RI7 \\
\hline mib & $\mathrm{mi}$ & fa & fa\# & sol\# & fá & lá & sol \\
\hline $10 x$ & $7 x$ & $5 x$ & $1 x$ & $4 x$ & $4 x$ & $3 x$ & $1 x$ \\
\hline $1 / 2$ Tom & $1 / 2$ Tom & $1 / 2$ Tom & $1 / 2$ Tom & 1 Tom & & & fermata \\
\hline
\end{tabular}

\begin{tabular}{|c|c|c|c|c|c|}
\hline \multicolumn{7}{|c|}{ parte A } \\
\hline RI3 & RI4 & RI5 & RI6 & RI7 & RI4 \\
\hline mib & mi & fá & fa\# & sol & mi \\
\hline $11 x$ & $8 x$ & $1 x$ & $1 x$ & $4 x$ & $3 x$ \\
\hline $1 / 2$ Tom & $1 / 2$ Tom & $1 / 2$ Tom & $1 / 2$ Tom & $1 / 2$ Tom & coda \\
\hline
\end{tabular}

Na parte A existe uma redução (compressão) do número de repetições da série até a série [RI8] que se funde com [R5] e que marca o início da parte B. A parte B termina com uma fermata e uma Generalpause para retornar à parte $\mathrm{A}$ já de forma transformada. Este retorno à parte A, se inicia com RI4 em aumentação entre contrapontos das outras vozes que usam a série RI3. Ocorre uma repetição da compressão em [RI7]. Na Coda final, a flauta faz uma grande diminuição em forma de arabescos virtuosos, para concluir a Sonata usando a série [RI4]. 


\section{7 - Conclusões}

Acreditamos ter demonstrado a conexão entre a atividade de Santoro como compositor e suas atividades práticas como instrumentista no período de criação desta obra, particularmente na influência barroca para a construção da Sonata para flauta. As evidências de suas atividades concertísticas, assim como a escolha do intérprete (Koellreutter) e a inclusão no repertório de um concerto da Sociedade Bach, corroboram essa hipótese. Analisando o período em que a obra foi escrita e a sua experiência no campo da composição dodecafônica, pode se concluir que Santoro possivelmente até tenha empregado uma escrita mais formal nesta Sonata em relação às digressões possíveis, comparando-a a outras obras do período, onde aparentemente sua flexibilidade no uso da técnica foi maior.

Demonstramos também que as chamadas "liberdades" técnicas que a literatura costuma atribuir à escrita dodecafônica de Santoro, na verdade são perfeitamente condizentes com os rigores do estilo, como demonstra a análise detalhada que empreendemos da construção da obra. É possível perceber que apesar do estágio ainda inicial do conhecimento da técnica dodecafônica no Brasil, em plena Guerra, Santoro já desenvolvera uma forma extremamente sofisticada e pessoal do uso de diversos recursos da técnica, não como uma camisa de força e nem como preocupação de seguir postulados da técnica de Schoenberg, que não havia como ele conhecer em detalhes, mas sim como forma de dar coesão, unidade e fundamento a todos os elementos utilizados nos alicerces arquitetônicos da Sonata para flauta.

\section{Referências}

1. Coelho de Souza, Rodolfo. 2012. A Recepção das Teorias do Dodecafonismo nos Últimos Quartetos de Cordas de Cláudio Santoro. Revista Brasileira de Música v.24, p. 329-350.

2. Kater, Carlos. 2001. Música Viva e H. J. Koellreutter. Movimentos em direção à modernidade. São Paulo: Musa.

3. Mendes, Sérgio Nogueira. 2009. O Percurso estilístico de Claudio Santoro, roteiros divergentes e conjunção final. Tese de Doutorado, UNICAMP.

4. Oliveira, Reinaldo Marques de. 2005. Cláudio Santoro e o Dodecafonismo: Um Procedimento Técnico Singular. Dissertação de Mestrado, USP. 
5. Potthoff, Ayres Estema. 1997. A música de câmara com flauta, composta por Claudio Santoro entre 1940 e 1946 uma abordagem fenomenológica. Dissertação de Mestrado, UFRJ.

6. Santoro, Cláudio. 1986. Contando a minha vida. Depoimento não publicado disponível no acervo Claudio Santoro.

7. Santoro, Cláudio. 1976. Entrevista concedida ao compositor Raul do Valle, em Heidelberg (Alemanha). Depoimento não publicado disponível no acervo Claudio Santoro.

8. Souza, Iracele Aparecida Vera Lívero de. 2003. Santoro: Uma História em Miniaturas: Estudo Analítico-interpretativo dos Prelúdios para Piano de Cláudio Santoro. Dissertação de Mestrado, UNICAMP. 


\section{$\underline{\text { ANEXOS }}$}

1. Exemplos de Concertos executados por H. J. Koellreutter - flauta, Claudio Santoro - violino e Gabriella Bailarin - cravo

1.1. Correio da Manhã - Rádio - Cruzada Nacional de Educação em 29/8/1940 Disponível em http://memoria.bn.br/DocReader/089842_05/2935

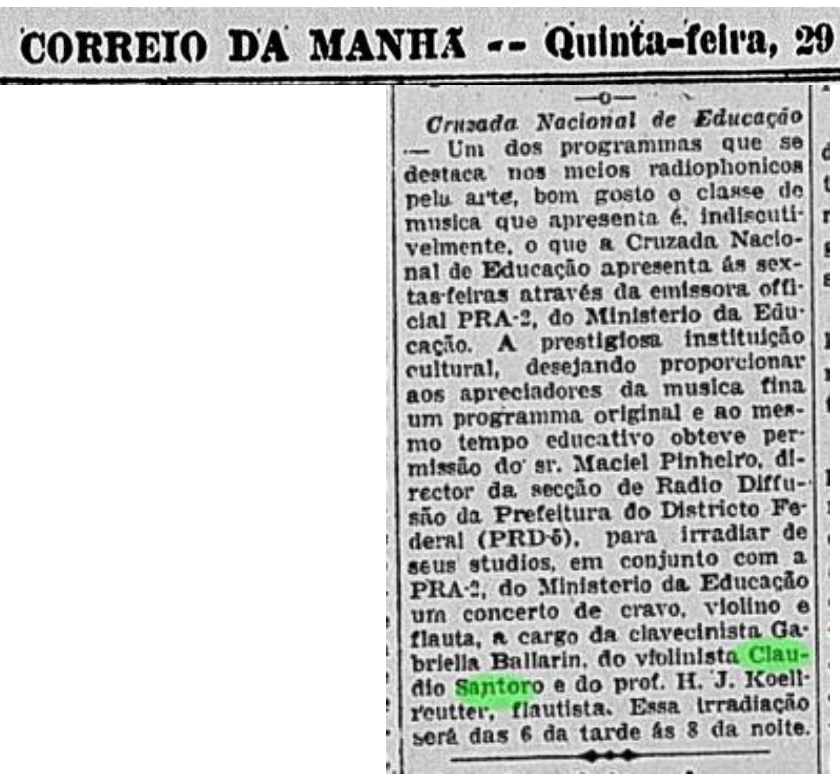

1.2. Correio da Manhã - Rádio - Cruzada Nacional de Educação em 30/8/1940 Disponível em http://memoria.bn.br/DocReader/089842_05/2947

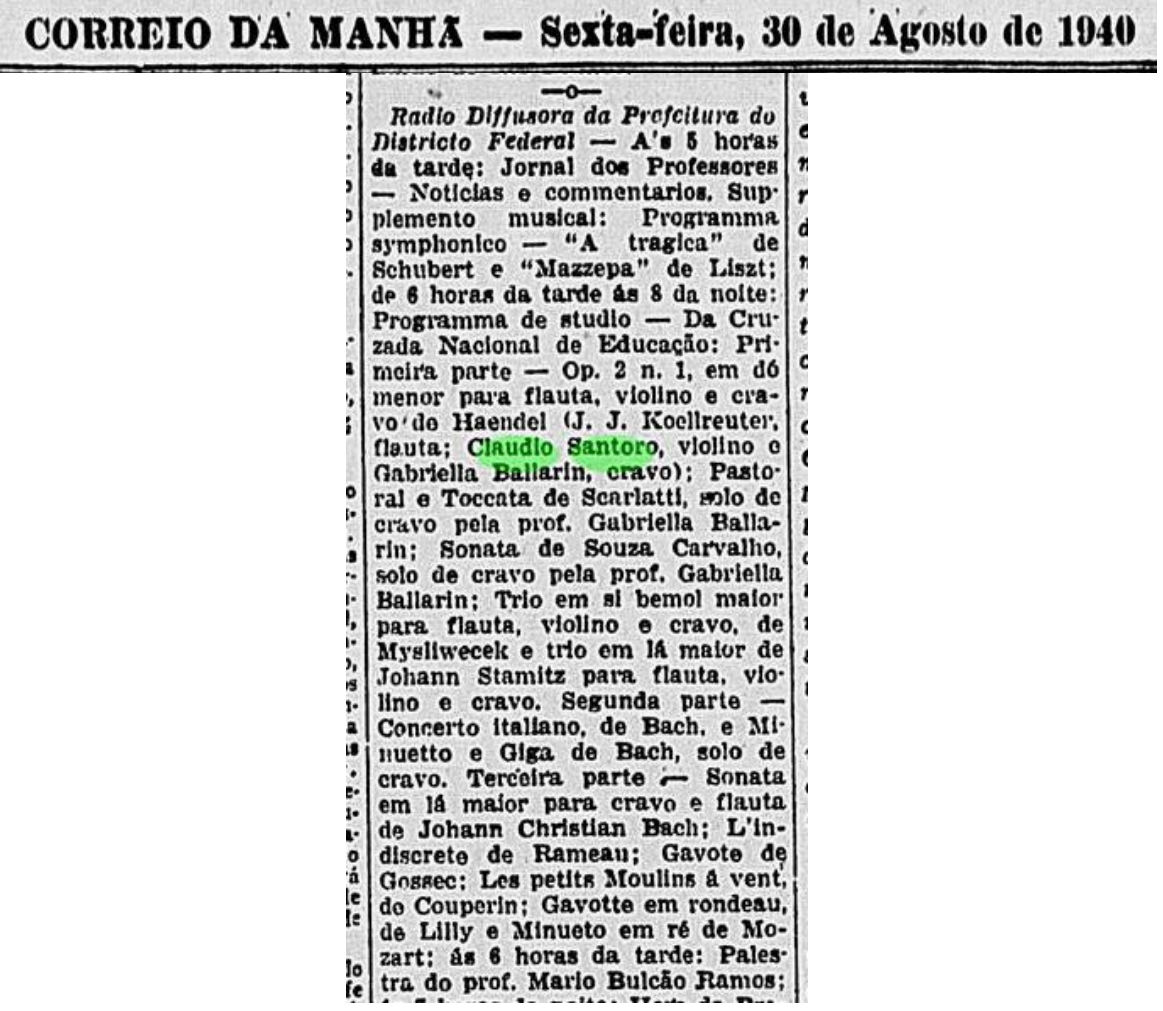

\section{MUSICA THEORICA}


1.3. Correio da Manhã - Rádio - 10/01/1941

Disponível em http://memoria.bn.br/DocReader/089842_05/4725

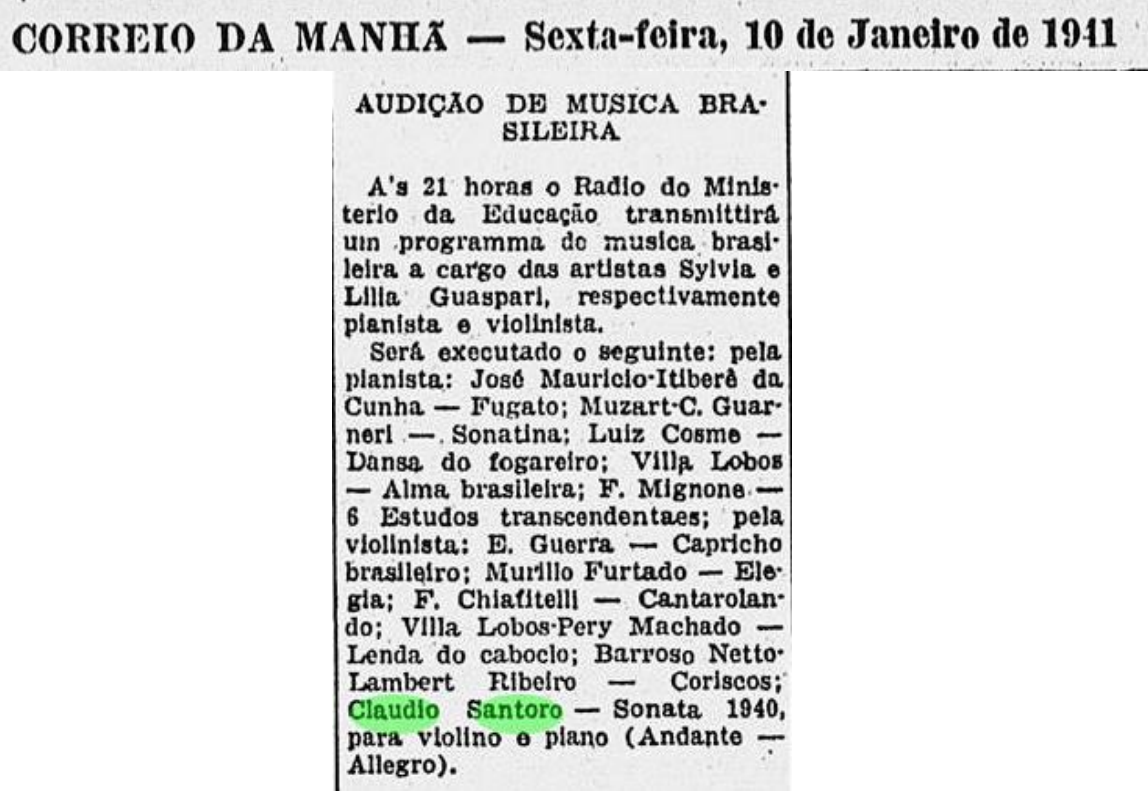

1.4. Correio da Manhã - Correio Musical - 5/10/1941

Disponível em http://memoria.bn.br/DocReader/089842_05/8810

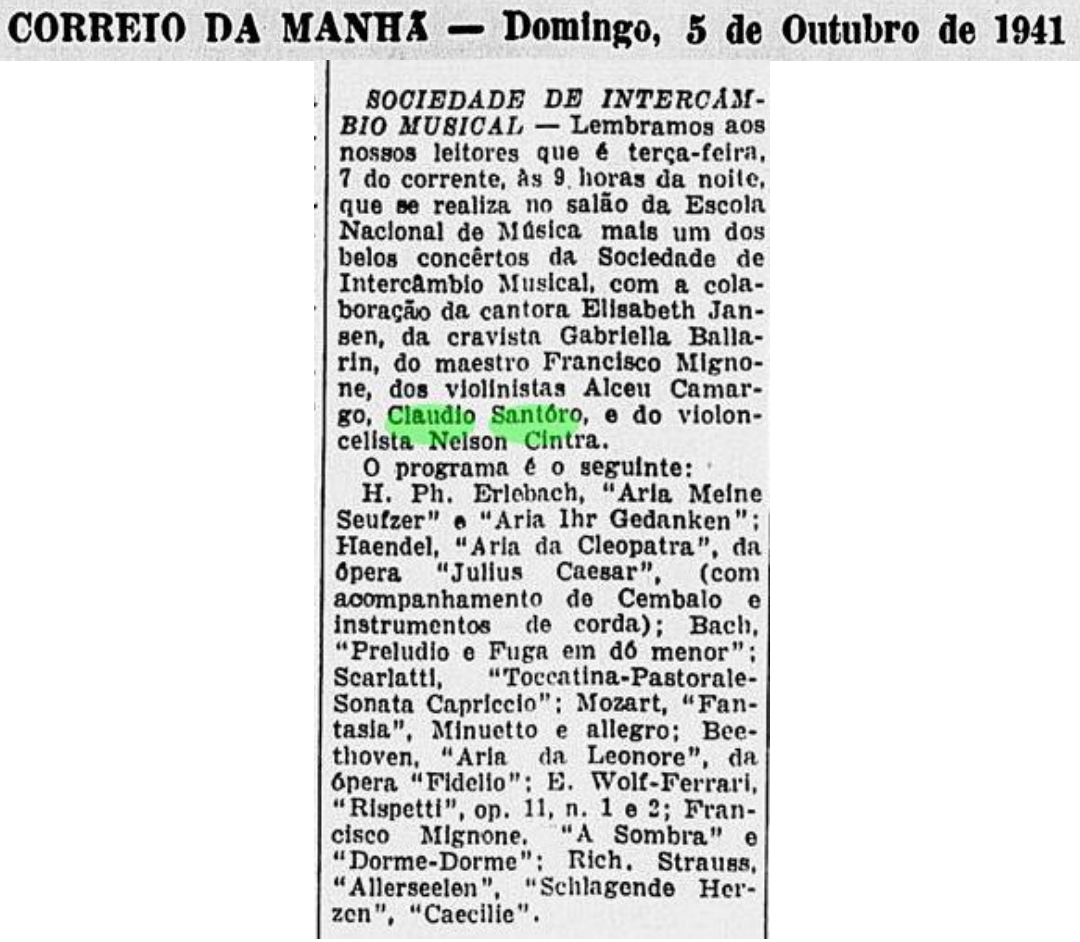

\section{MUSICA THEORICA}

Revista da Associação Brasileira de Teoria e Análise Musical Journal of the Brazilian Society for Music Theory and Analysis 
1.5. Correio da Manhã - Correio Musical em 19/10/1941

Disponível em http://memoria.bn.br/DocReader/089842_05/9030

\section{CORREIO DA MANHE - - Domingo, 19 de Outubro de 1941}

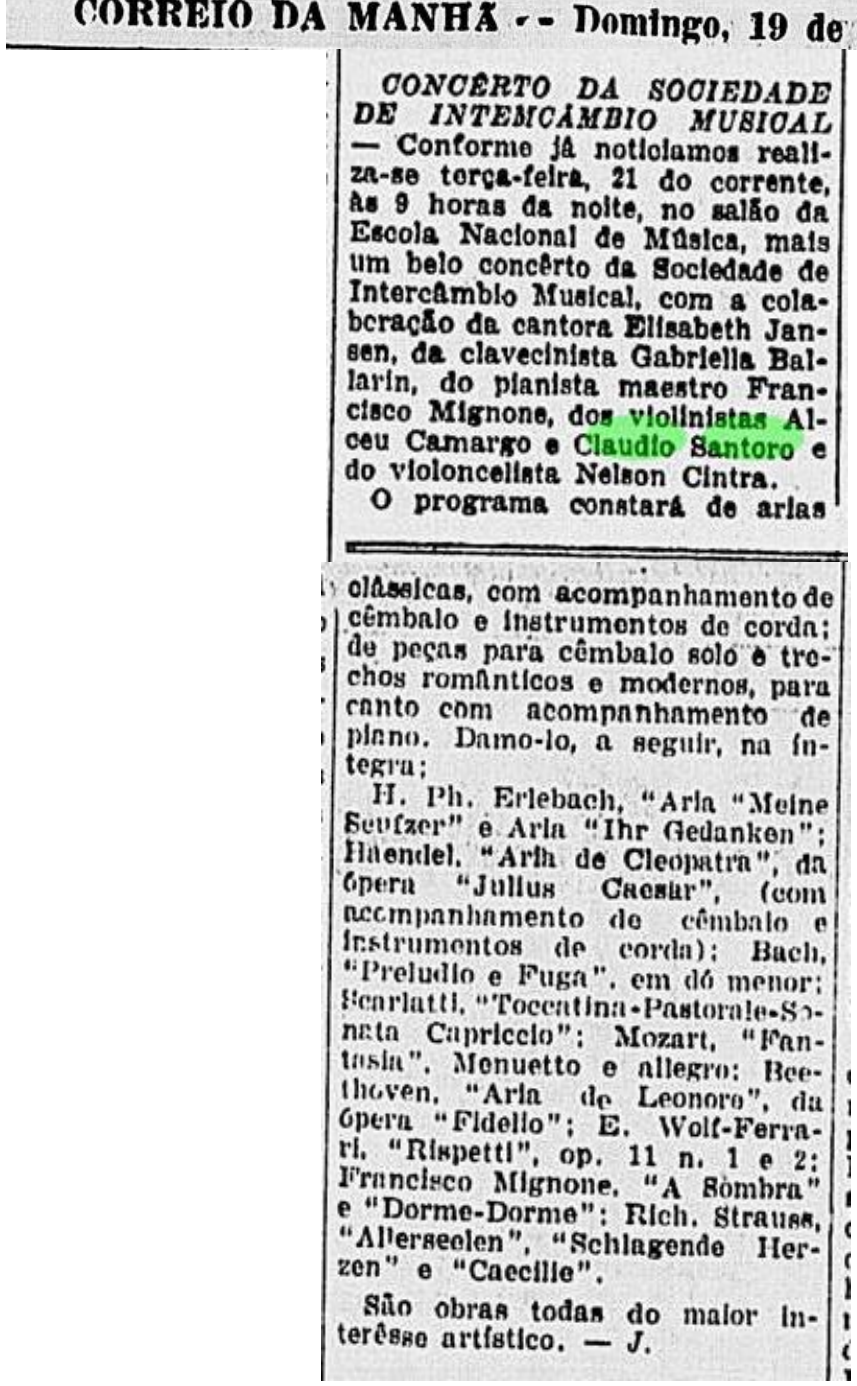

\section{MUSICA THEORICA}

Revista da Associação Brasileira de Teoria e Análise Musical Journal of the Brazilian Society for Music Theory and Analysis 
1.6. Correio da Manhã - Correio Musical em 23/10/1941

Disponível em http://memoria.bn.br/DocReader/089842_05/9078

CORREIO DA MANHA - Quinta-felra, 23 de Outibro de 1941

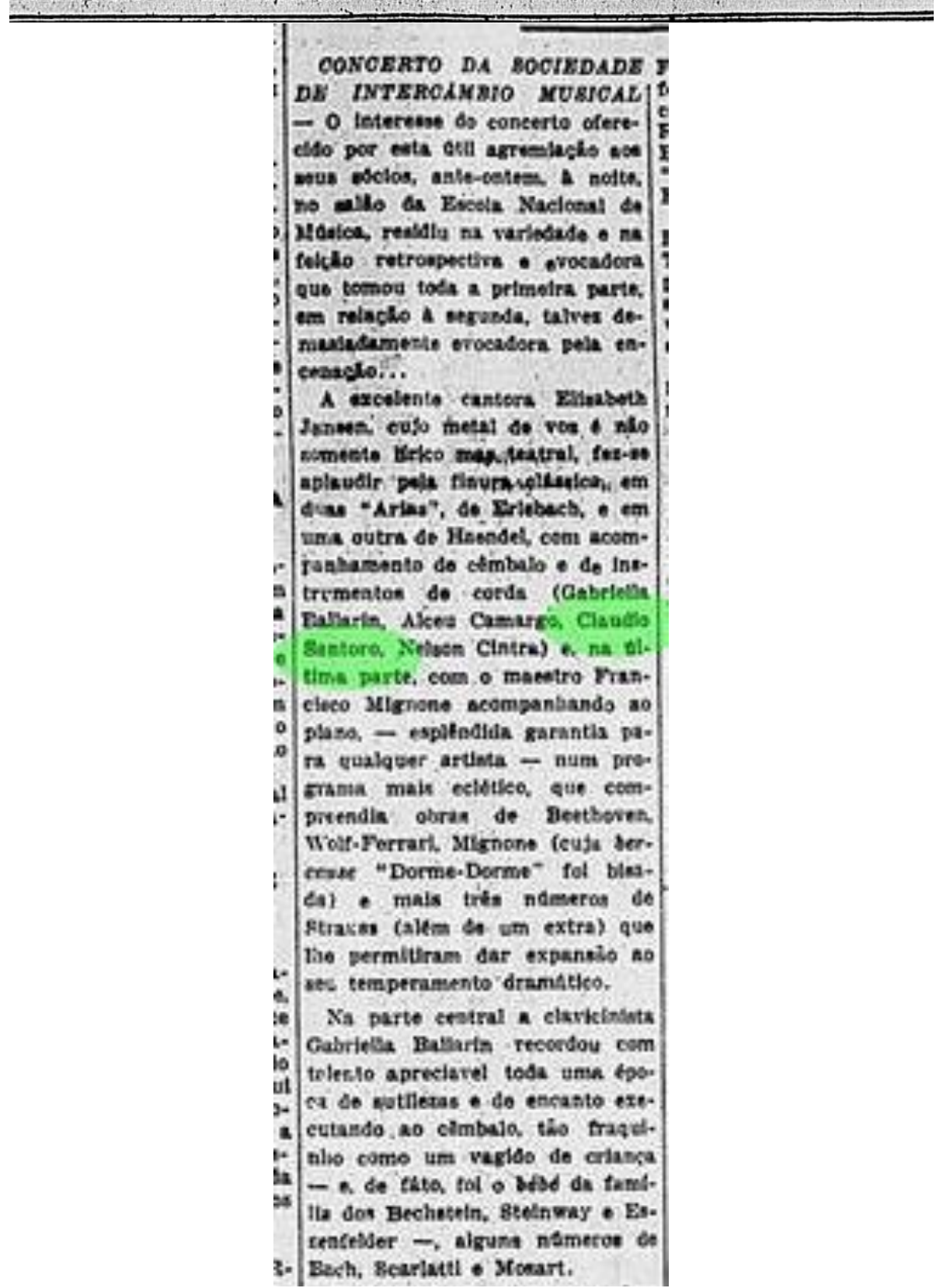

\section{MUSICA THEORICA}

Revista da Associação Brasileira de Teoria e Análise Musical Journal of the Brazilian Society for Music Theory and Analysis 
1.7. Correio da Manhã - Correio Musical em 28/02/1941

Disponível em http://memoria.bn.br/DocReader/089842_05/10599

CORREIO DA MANH

\section{CORREIO MUSICAL}

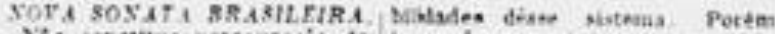

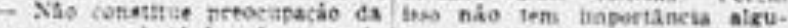

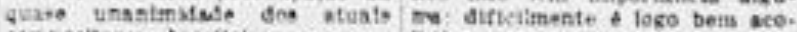

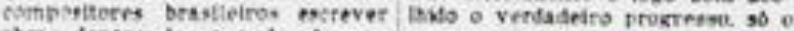
chers dentro dar grandet foemas tempo o imple a sotieralktade.

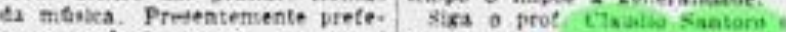

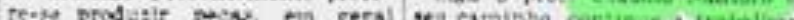

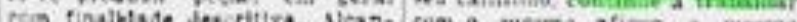

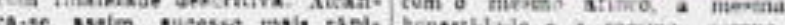
60. porve a

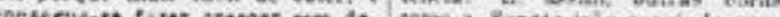

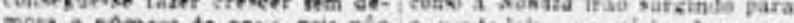

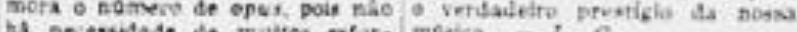

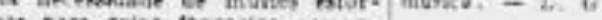

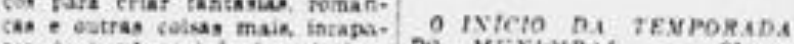

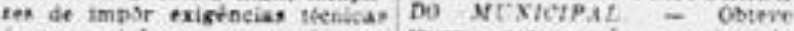

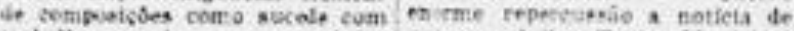

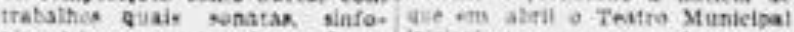

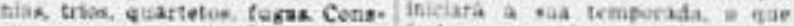

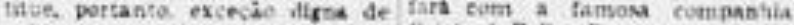

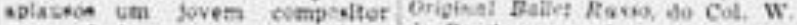

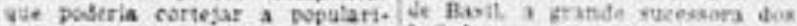

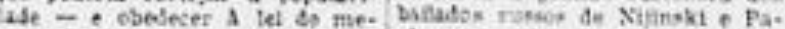

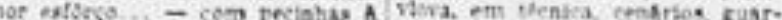

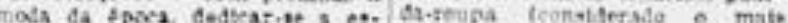

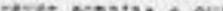
erma severa em aue nio fat tas beiera las pecos.

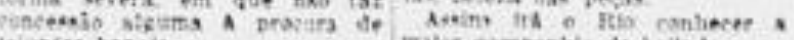

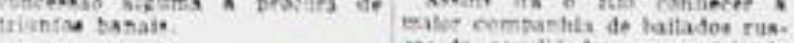

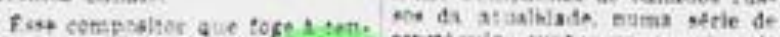

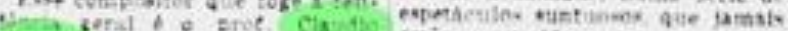

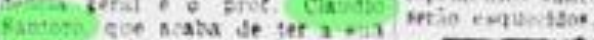

Ma sulo innituto interstnetics. As novas estampilhas pa-

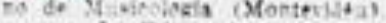

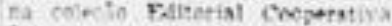

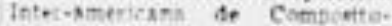
trt

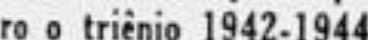

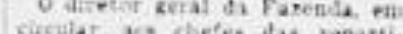

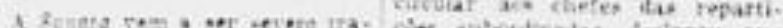

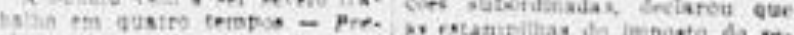

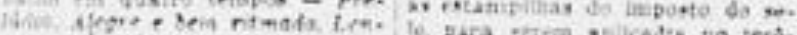

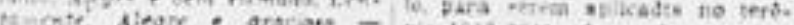

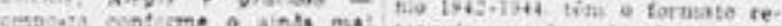

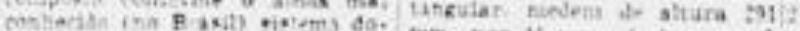

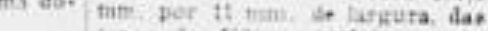

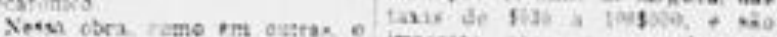

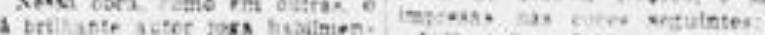

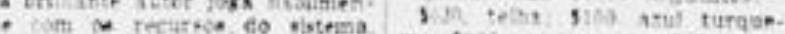

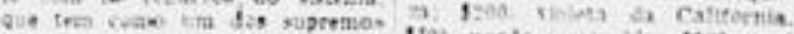

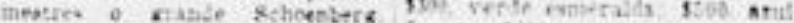

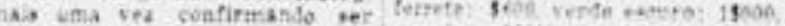

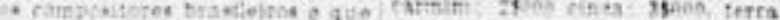

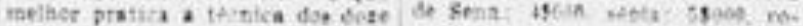

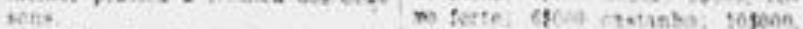

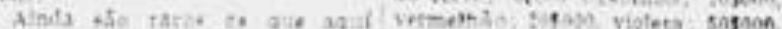

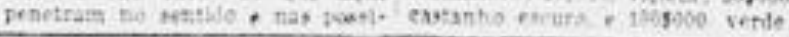


1.8. A Manhã (RJ) 3 de outubro de 1942 (data diferente do site da estreia) Matéria de Dinorah de Carvalho sobre estreia da Sonata para flauta de Santoro

\section{"SOCIEDADE BACH"}

Com obras de J. S. Bach, G. Fr. Haendel, Claudio Santoro, J. Paci. bel e G. Ph. Teleman, a "Sociedade Bach" ofereceu mais uma interessa: audicao aos seus sócios. Participaram desse programa, a distinta profess Tatiana Braunwieser (piano), H. J. Kollreuter (flauta), Alexandre Scho man $e$ Angelo Napoll (violinos), alem do conjunto vocal $e$ instrumental mesma sociedade, sob a direçá do maestro Braunwieser. Na primeira po te ouvimos a "Sonata em Dó. Maior" para dois violinos e piano, - Adís. Fuga, Canon e Gigue, e a "Sonata em Mi Menor", para dois violinos e no, op. 5 n. $3,-$ Andante, Allegro non troppo, Allegro, Sarabande, A mande, Rondeau, Gavotte. Tanto na "Sonata" de "Bach", como na "Haendel", os intérpretes demonstraram muita compreensáo musical e th. nica sólida. Os trés executantes tiveram oportunidade de provar sua caps cidade na interpretação dessas obras de grande responsabilidade e tâo rant mente incluidas em nossos programas. Encerrou a primeira parte 0 "Ca. funto Coral Misto", com a régéncia do maestro Braunwieser na ótima e: cuço dos corats de Bach: " $\delta$ Santo Espirito de Deus" $e$ "Libertos do P der do Mal", sendo a nota interessante terem sido cantados em nosso id ma. Esse fino confinto demonstrou apreciavets qualidades de equilibrio afinaça: Foram vivamente aplaudidos. Na ultima parte, ouvimos em metra audiçáo, a "Sonata para piano e flauta", de autoria do fovem comp sitor brsiletro, Claudio Santoro.

Essa sonata é atonal e nŏo tem influéncias folclóricas. Trata-se de : compositor bastante original, talvez o unico entre nós que escreve no tema "Schoenberg" em doze tons. A execuçăo do flautista Kollreuter, notavel, com a técnica perfeita e clareza de sonoridade. Em seguida ob: mos "Preludio para orquestra de cordas", de J. Pachebel. Esse composito dedicou-se quase exclusivamente a musica sacra, e é considerado um grandes mestres de orgäo, antes de J. S. Bach.

A orquestra e seu dirigente deu-nos uma interpretaçâo a contento of ral. Terminou o concerto com a "Suite em $L \dot{a} "$, de Telemann, para flauth solo, cravo e orquestra de cordas. Sendo a parte flautista a mais trabalk da, Kollreuter, venceu todas as dificuldades com uma técnica brilhantissins e em bom equilibrio com o conjunto orquestra.

\section{MUSICA THEORICA}

Revista da Associação Brasileira de Teoria e Análise Musical Journal of the Brazilian Society for Music Theory and Analysis 


\section{Música Viva}

\subsection{Correio da Manhã - Correio Musical em 10/01/1940}

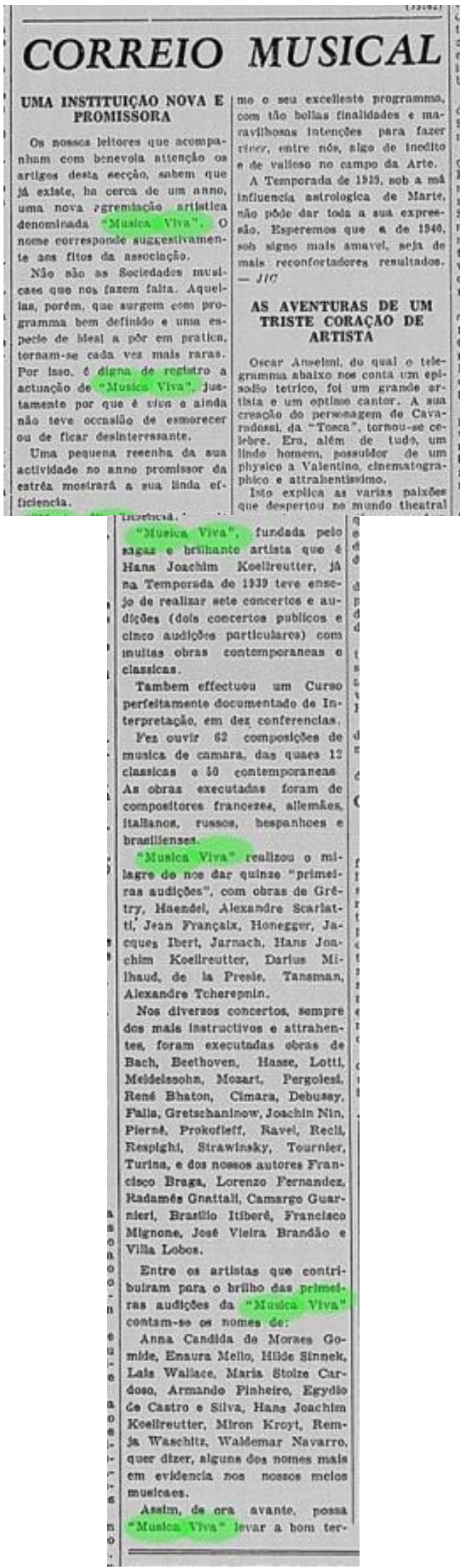

\section{MUSICA THEORICA}

Revista da Associação Brasileira de Teoria e Análise Musical Journal of the Brazilian Society for Music Theory and Analysis @ TeMA 2017 - ISSN 2525-5541 


\subsection{Correio da Manhã - Correio Musical em 10/05/1940}

\section{CORREIO MUSICAL}

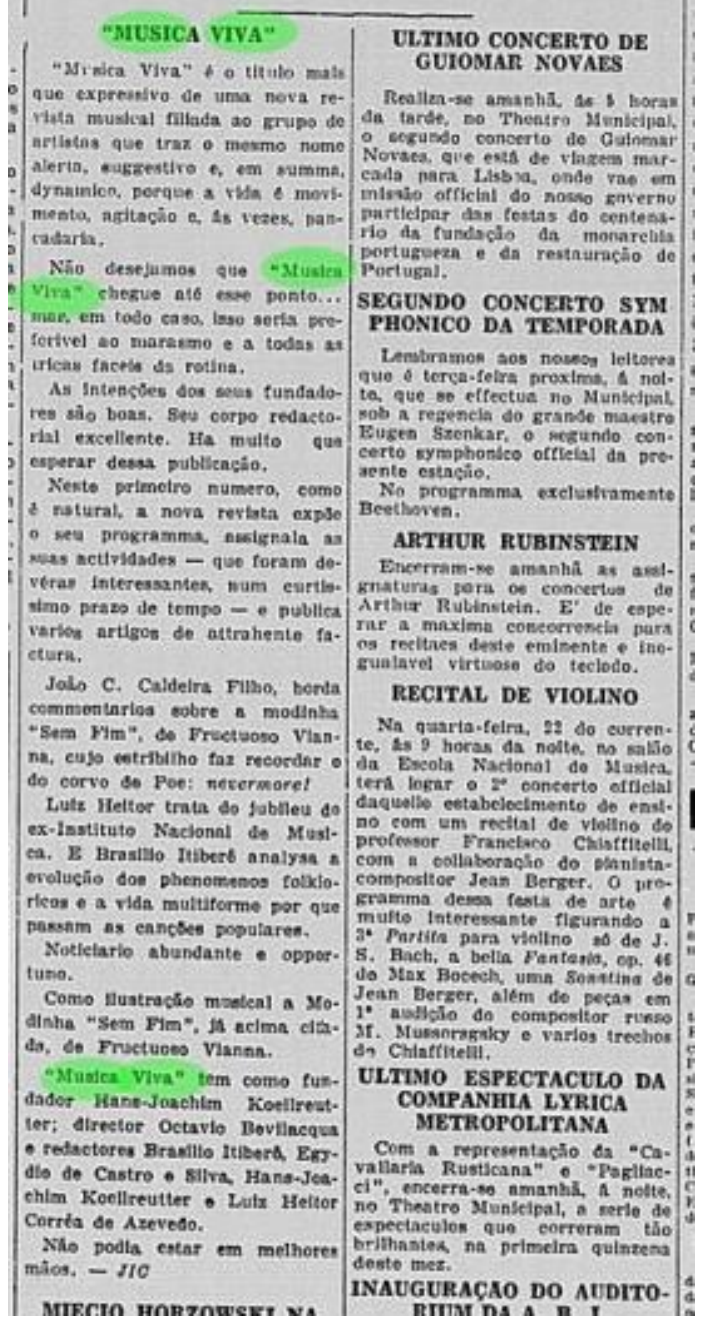

\section{MUSICA THEORICA}

Revista da Associação Brasileira de Teoria e Análise Musical Journal of the Brazilian Society for Music Theory and Analysis @ TeMA 2017 - ISSN 2525-5541 


\subsection{Correio da Manhã - Correio Musical em 11/05/1940}

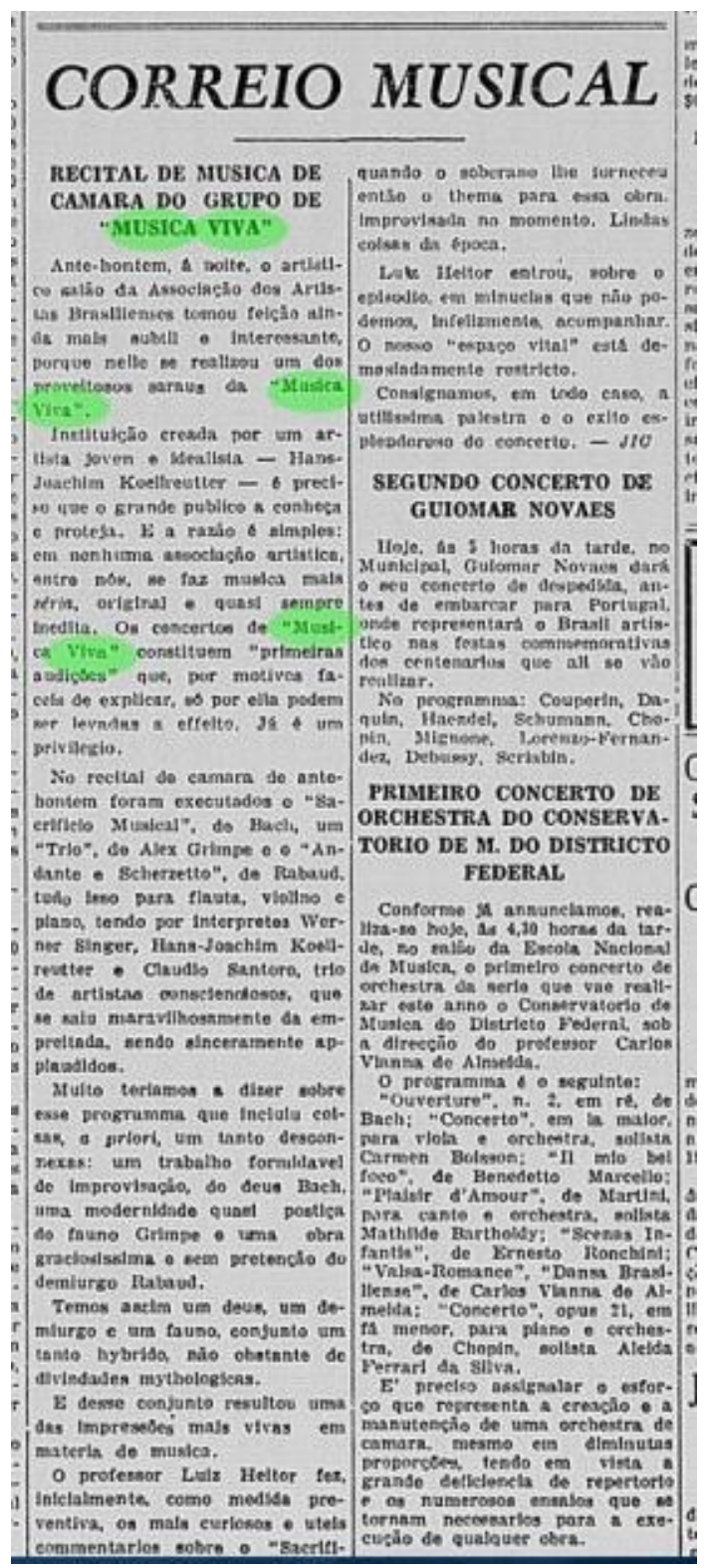

\section{MUSICA THEORICA}

Revista da Associação Brasileira de Teoria e Análise Musical Journal of the Brazilian Society for Music Theory and Analysis @ TeMA 2017 - ISSN 2525-5541 
2.4. Correio da Manhã - Correio Musical em 28/03/1941

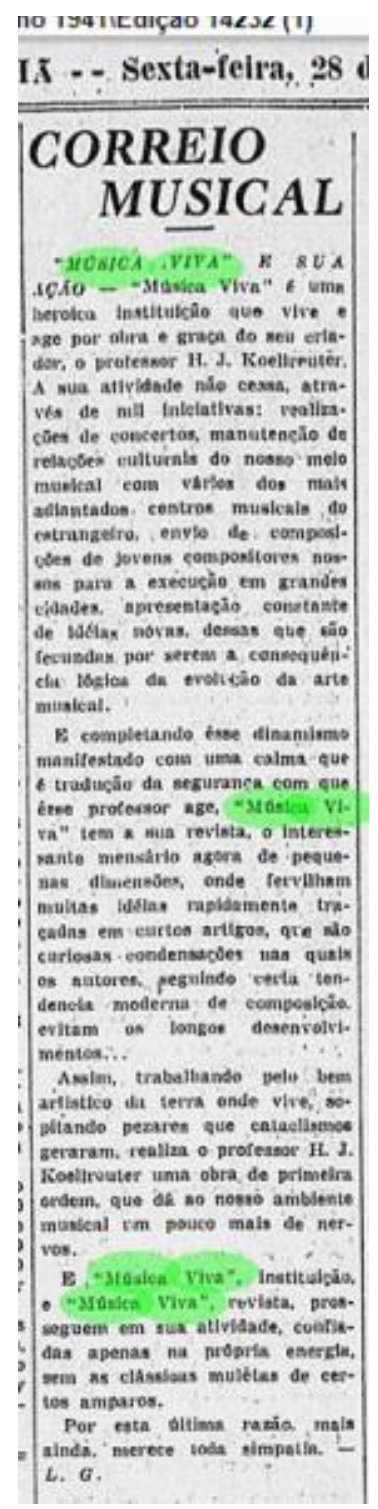

\section{MUSICA THEORICA}

Revista da Associação Brasileira de Teoria e Análise Musical Journal of the Brazilian Society for Music Theory and Analysis @ TeMA 2017 - ISSN 2525-5541 
2.5. Correio da Manhã - Correio Musical em 05/07/1941 Mudança de H. J. Koellreutter para São Paulo

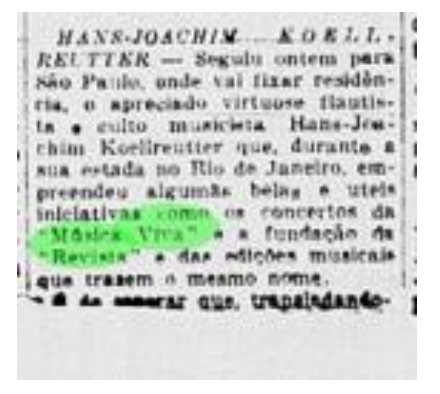

